\title{
Air Dispersion Modeling Of Mine Waste In The Southeast Missouri Old Lead Belt
}

\author{
M. L. Abbott
}

October 1999

Idaho National Engineering and Environmental Laboratory Bechtel BWXT Idaho, LLC 
INEEL/EXT-99-00235

Revision 0

\title{
Air Dispersion Modeling of Mine Waste in the Southeast Missouri Old Lead Belt \\ M. L. Abbott
}

\author{
Published October 1999 \\ Idaho National Engineering \\ and Environmental Laboratory \\ Integrated Earth Sciences Department \\ Idaho Falls, Idaho 83415 \\ Prepared for the \\ U.S. Department of Energy \\ Assistant Secretary for Environmental Management \\ Under DOE Idaho Operations Office \\ Contract DE-AC07-99ID13727
}




\section{ABSTRACT}

Past lead ore processing conducted in the Southeast Missouri Old Lead Belt since the 1700s has left numerous large areas of lead contamination in elevated piles of fine gravel waste called "chat" and dried-out tailings ponds. Wind suspension and atmospheric dispersion are known to transport these materials to the surrounding communities where the lead could pose a human health threat through inhalation or ingestion of the deposited contamination. The purpose of this study was to estimate potential wind suspension rates, perform dispersion modeling of the tailings and chat sources, and determine ground surface deposition rates and potential soil concentrations of lead in the surrounding areas. The results can be used to prioritize soil sampling locations, site air monitors, help identify the source of soil lead contamination, and to help develop remediation plans. Numerous, large complex sources in the region were parameterized into 33 area sources with the aid of digital aerial photos, digitized typographic maps, Geographic Information Systems (GIS) software, and site inspections. An AP-42 particulate emission model was used to estimate lower- and upper-bound hourly emission rates using six years of hourly wind speed data obtained from the St. Louis Airport. The emissions model accounted for wind speed, precipitation, source-specific aggregate size, fraction of vegetation cover, and site-specific lead concentrations. An alternative simplified method to calculate emissions from elevated chat piles was developed. The Fugitive Dust Model (FDM) was then used to calculate long-term average and maximum 24-hour deposition rates of lead over a $200 \mathrm{~km}^{2}$ region. Soil concentrations were estimated from modeled deposition rates, time of deposition (80 y) and an assumed surface $(0-5.08 \mathrm{~cm})$ mixing depth. Model performance was evaluated by comparing lower- and upper- bound modeled predictions to both air and soil sampling data obtained at two sites. The predicted-to-observed $(\mathrm{P} / \mathrm{O})$ ratios calculated using the geometric mean of the lower- and upper-bound modeled concentrations ranged from a low of 0.84 at $300 \mathrm{~m}$ to a high of 1.4 at $1800 \mathrm{~m}$, with an average of 1.1 . The $\mathrm{P} / \mathrm{O}$ ratios tended to increase slightly at distances beyond about $1 \mathrm{~km}$. These $\mathrm{P} / \mathrm{O}$ ratios demonstrate exceptional model performance for the particular sampling transect (location and direction) investigated. 


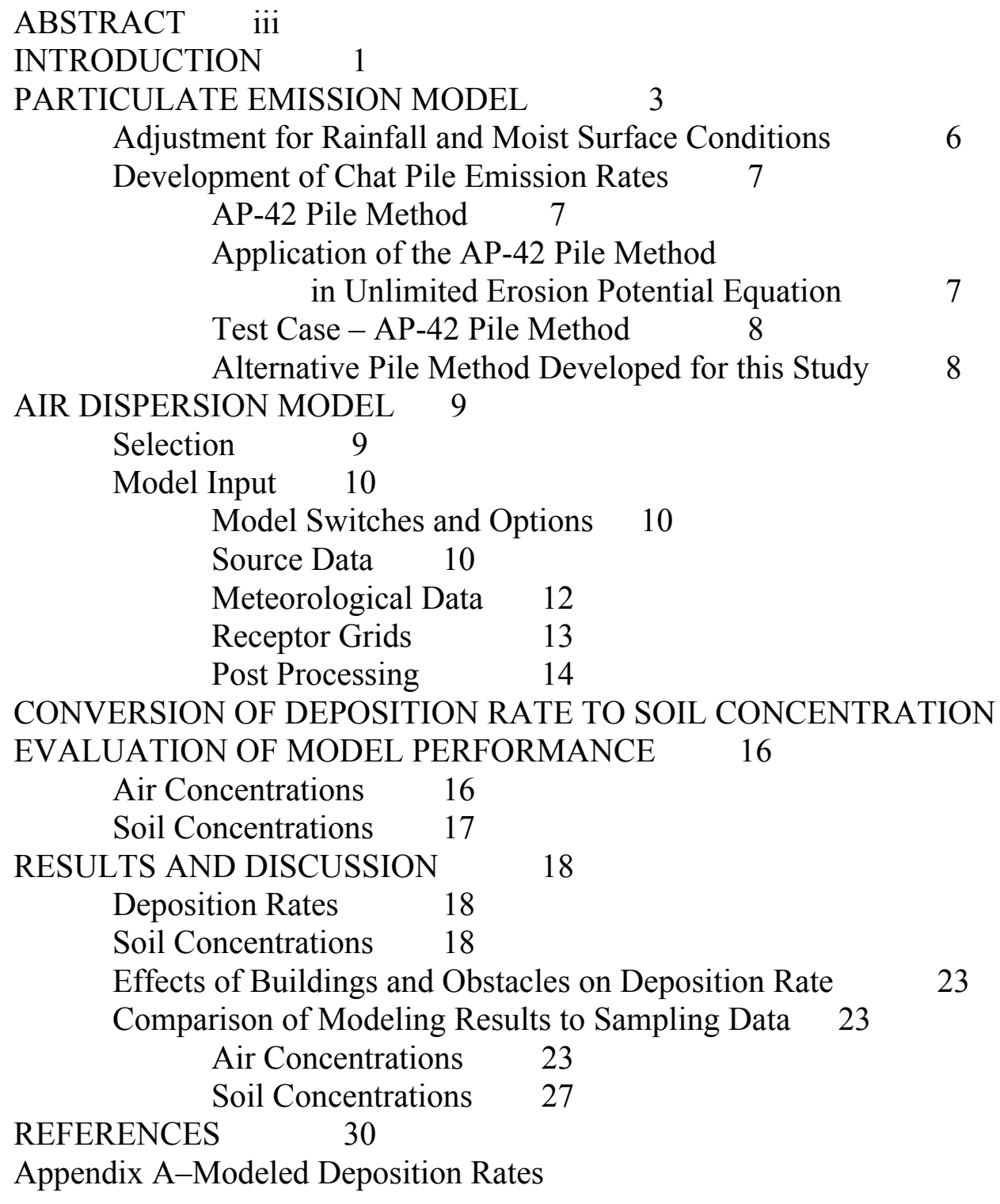

FIGURES

1. Base map of tailings flats and chat piles in the Old Lead Belt of Southeastern Missouri 2

2. Graph of function $\mathrm{F}(\mathrm{x})$ needed in equation (1) 4

3. Surface roughness height measurements for sand and tailings sources 5

4. Area sources and receptor grids used in the modeling 11

5. Location of TSP/lead air samplers at the Desloge site 16

6. Soil sampling locations and modeled deposition rate isopleths $\left(\mu \mathrm{g} \mathrm{m}^{-2} \mathrm{hr}^{-1}\right)$ at the Bonne Terre site 17

7. Predicted lead concentrations in undisturbed surface soils ( $\left.\mathrm{mg} \mathrm{kg}^{-1}\right)$ around the Bonne Terre tailings and chat sites $\quad 19$

8. Predicted lead concentrations in undisturbed surface soils ( $\left.\mathrm{mg} \mathrm{kg}^{-1}\right)$ around the Desloge tailings and chat sites 20

9. Predicted lead concentrations in undisturbed surface soils ( $\left.\mathrm{mg} \mathrm{kg}^{-1}\right)$ around the Federal tailings site and the National and Elvins chat piles

10. Predicted lead concentrations in undisturbed surface soils $\left(\mathrm{mg} \mathrm{kg}^{-1}\right)$ around the Leadwood site 22

11. Comparison of lower- and upper-bound model predictions to measured lead 
concentrations from the North sampler at the Desloge tailings site

12. Comparison of lower- and upper-bound model predictions to measured lead concentrations from the South sampler at the Desloge tailings site 25

13. Comparison of lower- and upper-bound model predictions to measured lead concentrations from the East sampler at the Desloge tailings site 26

14. Comparison of lower- and upper-bound model predictions to measured lead concentrations from the West sampler at the Desloge tailings site 26

15. Model predicted-to-observed $(\mathrm{P} / \mathrm{O})$ ratios of annual average air concentrations determined at the Desloge air samplers

16. Comparison of measured soil concentrations at the Bonne Terre tailings site with those calculated using modeled deposition rates

\section{TABLES}

1. Lead concentrations (ppm) at the tailings and chat sites 6

2. Surface to reference height $\left(\mathrm{u}_{\mathrm{s}} / \mathrm{u}_{\mathrm{r}}\right)$ wind speed ratios for oval piles

3. Particle size data used in the analysis

4. Source - receptor grid combinations evaluated in the modeling

5. Comparison of modeled and measured soil concentrations along the Bonne Terre East sampling transect 


\section{Air Dispersion Modeling of Wind-Suspended Mine Waste in the Southeast Missouri Old Lead Belt}

\section{INTRODUCTION}

Past lead mining operations conducted in the Old Lead Belt of southeastern Missouri since the 1700s, have left large areas of soil contamination. These areas consist of "tailings" flats composed of sand and silt-size waste and large "chat" piles composed of a coarser, fine gravel- size waste. Four primary tailings areas exist (Bonne Terre, Desloge, Federal, and National), some as large as $2 \mathrm{~km}$ across (Figure 1). Five major chat piles exist (Bonne Terre, Desloge, National, Elvins, and Leadwood), the largest (National) measuring up to 61-m high and 800-m across. Lead concentrations at these sources average from 2000 to $7000 \mathrm{ppm}$. These areas produce wind-borne dust emissions that are blown throughout the surrounding communities of Bonne Terre, Desloge, Elvins, Esther, Flat River, Leadington, Leadwood, and Rivermines. Because of the lead content in the blowing dust, yards, outdoor playthings, and homes can become contaminated. This can pose a human health threat, especially to children, through ingestion and inhalation of the contaminated dust. The area is currently a CERCLA Superfund site being administered by EPA Region 7.

As part of their site characterization, EPA requested that air dispersion and deposition modeling be performed to assess the ground deposition rates of airborne lead in the region. The modeling results will be used to prioritize soil sampling locations, site air monitors, help develop remediation plans, and help identify the source of soil lead contamination in specific areas. The modeled ground deposition rate at a particular location can be converted to the soil lead concentration that is attributable to mine waste dispersion by multiplying by the time a source has been in existence and an assumed surface soil mixing depth.

The main objectives of this evaluation were to calculate contaminant emission rates, perform air dispersion and deposition modeling of these emissions, and to predict soil lead concentrations around each of the facilities. Emission rates were calculated outside of the air dispersion model using a published particulate emission model that has been developed from experimental field studies. These emission rates were then input into the Fugitive Dust Model $(\mathrm{FDM})^{1}$ which simulates downwind air dispersion and calculates air concentrations and ground deposition rates across a grid of downwind receptor locations. FDM output was then averaged over the six years of meteorological data and plotted as isopleth maps using contouring software. Soil concentrations were estimated from modeled deposition rates, time of deposition (80 years) and an assumed surface mixing depth $(0-5.08 \mathrm{~cm})$. Model performance was evaluated by 1$)$ comparison of lower- and upper-bound modeled air concentrations to air monitoring sampling data from four air monitors located near the Desloge site and 2) comparison of soil sampling data near the Bonne Terre site with those calculated using the modeled deposition rates. 


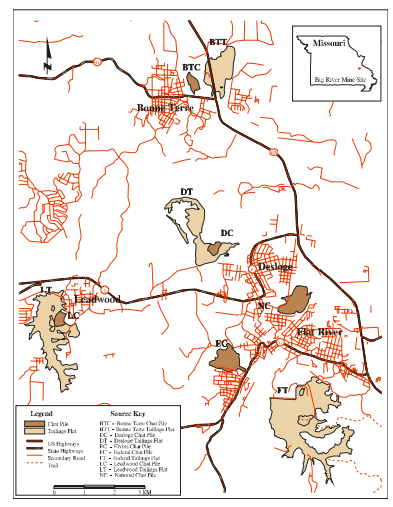

Figure 1. Base map of tailings flats and chat piles in the Old Lead Belt of Southeastern Missouri. 


\section{PARTICULATE EMISSION MODEL}

Particulate fluxes (mass suspended per unit area per unit time) are required as input to an air dispersion model and are generally calculated outside of the air model. Three general types of empirical emission factor equations exist for wind suspension of $\mathrm{dust}^{2}$ : 1) wind erosion from surfaces with a "limited reservoir" of erodible material, 2) wind erosion from highly erodible surfaces with an "unlimited reservoir" of erodible material, and 3) wind erosion from areas that are frequently disturbed. Other equations exist for particulate suspension by mechanisms other than the wind (e.g. from vehicle traffic or heavy equipment operations). An "unlimited" wind erosion potential model was selected for use in this study based on observations of wind-initiated dust plumes in the region and the characteristics of the tailings and chat sources (bare surfaces of finely divided material that exist to a significant depth). Although vehicle and equipment disturbance sometimes exist at some of the sources, this could not be adequately quantified for all the sources and was assumed to be relatively small compared to long-term suspension by the wind.

The unlimited erosion potential emission factor equation used in this study ${ }^{3}$ was developed from Gillette's 1981 field measurements of highly erodible soils ${ }^{4}$ :

where

$$
\begin{aligned}
& E_{10}=\text { annual average } P_{10} \text { emission factor }\left(\mathrm{g} \mathrm{m}^{-2} \mathrm{hr}^{-1}\right) \\
& \mathrm{V}=\text { fraction of contaminated surface vegetative cover }(0 \text { for bare soils }) \\
& \mathrm{u}_{\mathrm{r}}=\text { mean annual wind speed at the anemometer reference height }(\mathrm{m} / \mathrm{s}) \\
& \mathrm{u}_{\mathrm{t}}=\text { threshold value of wind speed at the anemometer height }(\mathrm{m} / \mathrm{s}) \\
& \gamma=\text { given a value of } 3 \text { in Cowherd }(1985)^{3} \\
& \mathrm{x}=0.886 \mathrm{u}_{\mathrm{t}} /\left[\mathrm{u}_{\mathrm{r}}\right]=\text { dimensionless ratio } \\
& \mathrm{F}(\mathrm{x})=\text { function plotted in Figure } 2
\end{aligned}
$$

Several aspects of this equation were modified for application in this study. First, total suspended particulate (TSP) flux was estimated by multiplying the $\mathrm{PM}_{10}$ emissions from equation (1) by a factor of 2 which is the ratio of the $<30 \mu \mathrm{m}$ aerodynamic particle size multiplier (1.0) to the $<10 \mu \mathrm{m}$ particle size multiplier (0.5) given for typical fugitive dust emissions in AP-42 5 . Second, in order to predict maximum 24-hour deposition rates and to refine the annual average predictions, 1-hour averaged emission rates were calculated using hourly wind speeds for $u_{r}$ over six years of St. Louis meteorological data. Third, the value given for $\gamma(=3)$ in Cowherd $(1985)^{3}$ was assumed to be a lower-bound value based on earlier work by Gillette 6 who found a value of approximately 5 for fine sand textured soils similar to the tailings 
evaluated in this study. This value (5) was used in this study for calculation of upper-bound emission rates.

The $\mathrm{F}(\mathrm{x})$ function scales the emission rate calculated in the basic equation by factors ranging from 0.3 to 1.9 depending on the ratio of the threshold-to-anemometer wind speed. To calculate $\mathrm{F}(\mathrm{x})$ on an hourly basis, a polynomial equation was fitted to the curve plotted in reference 3 (Figure 2). For simplicity, $\mathrm{F}(\mathrm{x})$ was assumed to be equal to 0 for values of $\mathrm{x}$ greater than 2.0.

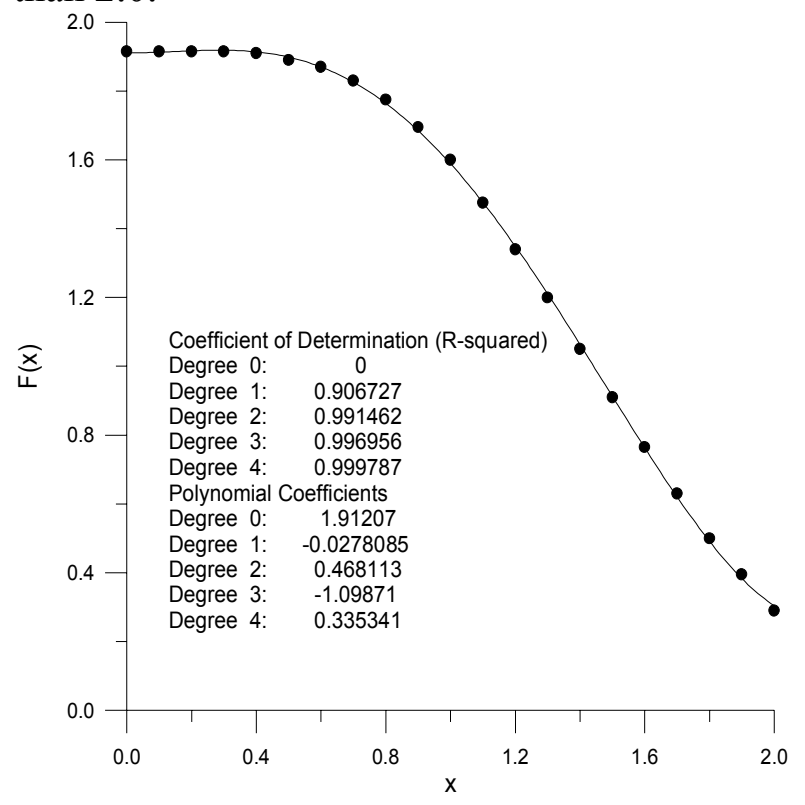

The threshold value of wind speed $\left(\mathrm{u}_{\mathrm{t}}\right)$ at anemometer height $(\mathrm{z})$ is calculated by

where

$$
\begin{aligned}
& \mathrm{u} *_{\mathrm{t}}=\text { threshold friction velocity }(\mathrm{m} / \mathrm{s}) \\
& \mathrm{z}_{0}=\text { surface roughness height of the source }(\mathrm{m})
\end{aligned}
$$

For uncrusted surfaces characteristic of the tailings and chat in this study, the threshold friction velocity can be determined from the mode of the aggregate size distribution using an empirical relationship derived by Gillette ${ }^{7}$ and presented as a graph in reference 3 . The surface roughness height is determined by the vertical wind velocity profile over the source but may be estimated from published measurements over surfaces with similar soil characteristics (smoothness, aggregate size mode, presence of nonerodible elements [larger rocks]). The emission rate calculated in equation (1) is very sensitive to the values selected for these two 
parameters, and both parameters are difficult to estimate across the large sources found in this study. Because of this uncertainty, lower- and upper-bound values for these parameters were estimated, producing lower- and upper-bound emission rates which were evaluated in the air modeling.

Values for threshold friction velocity $\left(\mathrm{u} *_{\mathrm{t}}\right)$ were estimated from a combination of aggregate size measurements (sieving) at a limited number of sites, previously published grain size analyses from surface samples (less than 20-ft.) at the Desloge site ${ }^{\mathrm{a}}$, and published measurements made at other tailing sites ${ }^{2}$. For the fine-grained tailings sources, threshold friction velocities were estimated to range from $20 \mathrm{~cm} / \mathrm{s}$ (upper-bound emission rate) to $25 \mathrm{~cm} / \mathrm{s}$ (lower-bound emission rate) on average across each source. These values correspond to an aggregate size mode ranging from $0.075 \mathrm{~mm}$ to $0.11 \mathrm{~mm}$. For the coarse-grained chat sources, threshold friction velocities were estimated to range from $56 \mathrm{~cm} / \mathrm{s}$ to $62 \mathrm{~cm} / \mathrm{s}$ which correspond to aggregate size modes of $0.7 \mathrm{~mm}$ and $0.9 \mathrm{~mm}$.

Figure 3. Surface roughness height measurements for sand and tailings sources.

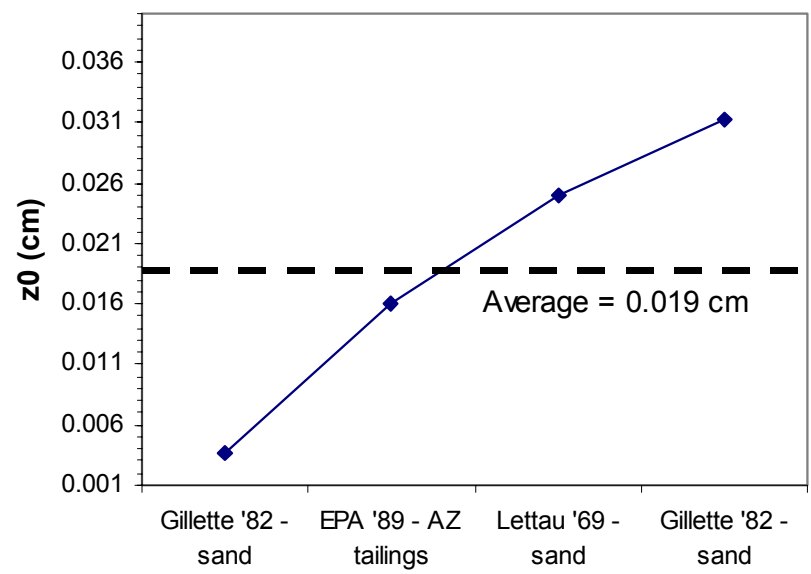

Values for surface roughness height $\left(\mathrm{z}_{0}\right)$ were estimated from published measurements made for similar soils (sand, tailings) ${ }^{2,8-9}$ (Figure 3). Based on this data, surface roughness height was assumed to range from 0.002 to $0.1 \mathrm{~cm}$ for tailings flats and from 0.5 to $1.0 \mathrm{~cm}$ for chat piles (higher $\mathrm{z}_{0}$ values result in higher emission rates). It is important to note that the $\mathrm{z}_{0}$ value selected for use in the emission factor equation should be representative of a small area at the source and is therefore likely to be much smaller than the value that would be appropriate for input into the air model to calculate regional air dispersion.

Hourly emission rates of lead $\left(\mathrm{R}_{30}\right)$ were calculated on a source-specific basis by:

where 


$$
\begin{aligned}
& \alpha=\quad \text { average mass fraction of lead at a specific source }\left(\mathrm{ppm} \mathrm{Pb} \times 10^{-6}\right) \\
& \mathrm{r}=\quad \mathrm{PM}_{10} / \mathrm{TSP} \text { ratio for fugitive dust }(0.5) \text { given in } \mathrm{AP}-42^{5}
\end{aligned}
$$

The average lead concentrations at the sources range from 2077 ppm (Desloge) to a high of 4392 ppm at the Elvins chat pile (Table 1) ${ }^{10}$. Site-specific PM-10 and TSP measurements taken over a 15-month period at the Desloge site indicated a PM-10/TSP ratio of 0.53 , which compares favorably with the AP-42 value (0.5) used in this analysis.

Table 1. Lead concentrations (ppm) at the tailings and chat sites.

\begin{tabular}{l|c|c}
\hline \hline \multicolumn{1}{c|}{ Site } & Mean & 95\% Confidence Interval \\
\hline Leadwood & 2444 & $2455-3231$ \\
\hline Desloge & 2077 & $1931-2224$ \\
\hline National & 3508 & $3172-3844$ \\
\hline Elvins & 4392 & $4130-4654$ \\
\hline Bonne Terre & 3515 & $3285-3744$ \\
\hline Federal & $3000^{\mathrm{a}}$ & Not available \\
\hline
\end{tabular}

a. Value obtained from the EPA site supervisor

\section{Adjustment for Rainfall and Moist Surface Conditions}

A final adjustment to the hourly emission rates was done to account for the reduction/elimination of fugitive dust emissions during periods of rain due to moist surface conditions. Hourly rainfall data ( $\mathrm{mm} /$ hour) were obtained from the St. Louis airport for the same 6-year period as the surface wind data (see Meteorological Data). One-hour emission rates $\left(\mathrm{R}_{30}\right.$ ) were then "zeroed-out" if rainfall was recorded for that hour or the previous hour. This adjustment reduced the annual flux from the sources calculated from wind speeds alone by $6 \%$ to $28 \%$ (typically about $10 \%$ ).

\section{Development of Chat Pile Emission Rates}

Hourly emission rates are more difficult to assess for chat piles because 1) the pile extends into the surface layer winds which exhibit a logarithmic velocity profile with height above the surface, 2) surface wind velocity varies laterally and temporally across the pile depending upon pile shape and orientation relative to hourly winds, and 3) complex eddy effects occur on the downwind (lee) side of the pile.

\section{$\underline{\text { AP-42 Pile Method }}$}

The AP-42 guidance 5 for calculating pile emission rates is based on a wind tunnel study that evaluated $11-\mathrm{m}$ high coal piles. Basically, the procedure involves subdividing a pile into several sources based on wind tunnel-observed subareas with similar surface (measured at 0.25 $\mathrm{m}$ in the wind tunnel study) to reference height $(10 \mathrm{~m})$ wind speed ratios $\left(\mathrm{u}_{\mathrm{s}} / \mathrm{u}_{\mathrm{r}}\right.$ values $)$. A different wind speed-dependent emission rate is calculated for each subarea and multiplied by 
the subarea's fraction of the total pile surface area. Each subarea is then modeled separately using its calculated subarea emission rate. Subarea $\mathrm{u}_{\mathrm{s}} / \mathrm{u}_{\mathrm{r}}$ ratios are provided for contoured areas within conical and oval with flat-top pile shapes and three basic wind directions. For the oval pile shape characteristic of the chat piles in this study, the following $\mathrm{u}_{\mathrm{s}} / \mathrm{u}_{\mathrm{r}}$ values are given (Table 2):

Table 2. Surface to reference height $\left(\mathrm{u}_{\mathrm{S}} / \mathrm{u}_{\mathrm{r}}\right)$ wind speed ratios for oval piles.

\begin{tabular}{l|l|c}
\hline \hline \multicolumn{1}{c|}{$\mathbf{u}_{\mathbf{s}} / \mathbf{u}_{\mathbf{r}}$} & \multicolumn{1}{|c|}{ Subarea Location } & Percent of Pile \\
\hline 0.2 & lower windward edge & $3-5$ \\
\hline 0.2 & top & $0-2$ \\
\hline 0.2 & lower lee edge & $25-29$ \\
\hline 0.6 & windward, mid-height & $22-26$ \\
\hline 0.6 & top & $26-29$ \\
\hline 0.9 & upper windward edge & $14-15$ \\
\cline { 3 - 3 } 1.1 & side windward edge & $3-4$ \\
\hline \hline
\end{tabular}

\section{Application of the AP-42 Pile Method in Unlimited Erosion Potential Equation}

In order to use this procedure with the emissions equation (1) selected for this study, the following steps were taken:

1. Hourly wind speeds from the St. Louis meteorological data were converted from the anemometer height $[\mathrm{u}(6.1 \mathrm{~m})]$ to the wind tunnel reference height $[\mathrm{u}(10 \mathrm{~m})]$ by where a typical pile roughness height of $0.5 \mathrm{~cm}(0.005 \mathrm{~m})$ has been assumed.

2. Hourly surface (at $0.25 \mathrm{~m})$ wind speeds $\left(\mathrm{u}_{\mathrm{S}}\right)$ were calculated for each subarea $\left(\mathrm{u}_{\mathrm{s}} / \mathrm{u}_{\mathrm{r}}=\right.$ $0.2,0.6,0.9$, and 1.1$)$ by

3. Surface wind speeds for each subarea were converted to reference wind speeds at the 6.1$\mathrm{m}$ anemometer height by

4. The 6.1-m anemometer height reference wind speeds $\left(\mathrm{u}_{\mathrm{r}}\right)$ were then used in equation (1) to calculate hourly emission rates for each subarea.

\section{$\underline{\text { Test Case - AP-42 Pile Method }}$}

Hourly emission rates of total dust $\left(\mathrm{E}_{30}\right)$ were calculated over one year (1984) of wind data for a $60-\mathrm{m}$ high pile using the above procedures and for an equivalent flat area using the unmodified anemometer-height wind speeds in equation (1). Threshold velocity [ $\mathrm{u}_{\mathrm{t}}$, in equation (1)], was calculated based on an assumed chat aggregate size mode of $0.9 \mathrm{~mm}$.

The total annual flux (sum of hourly rates) for the flat area was calculated to be $109 \mathrm{~g} / \mathrm{m}^{2}$ and required calculation of 8760 hourly emission rates. The AP-42 pile method required calculation of 35,040 hourly emission rates (8760 hours x 4 subareas) and resulted in a total 
annual flux of $295.7 \mathrm{~g} / \mathrm{m}^{2}$. This is a factor of 2.7 greater than emissions calculated for an equivalent (same aggregate size) flat area [using $\mathrm{u}(6.1 \mathrm{~m})]$.

\section{Alternative Pile Method Developed for this Study}

Due to the large number of calculations required for the AP-42 pile method and the increased number of sources that would be required for modeling, an alternative simplified method was developed for this study. The alternative method assumes that average emissions over the total pile surface area can be estimated by increasing the anemometer-height wind speeds to those which would occur at some higher elevation on the pile. The increased wind speeds are then used for $u_{r}$ in equation (1) instead of the anemometer height wind speeds, and the pile is modeled as a single source.

To determine an appropriate height at which to correct the wind speeds, total annual fluxes were calculated using hourly wind speeds at various heights between the 6.1-m anemometer height and the top of a $60-\mathrm{m}$ high pile. The results were compared to those calculated using the AP-42 pile method. A height of $45 \mathrm{~m}(0.75 \mathrm{x}$ pile height $)$ resulted in a total annual flux of $296.2 \mathrm{~g} / \mathrm{m}^{2}$, nearly identical to that calculated using the AP-42 pile method (295.7

$\mathrm{g} / \mathrm{m}^{2}$ ). Based on this, the hourly emission rates calculated for this study used reference wind speeds [ $u_{r}$ in equation (1)] that were corrected from anemometer height to $0.75 \mathrm{x}$ pile height. For a 60-m high pile, this increases the reference height wind speeds by a factor of 1.28 :

For the meteorological years examined in this study $(1984-1990)$, this method gives annual flux rates that are factors of 2.6 to 2.9 higher than those calculated for an equivalent (aggregate size) flat area. The method is considered to be equivalent to the AP-42 pile methodology but is much simpler to calculate.

\section{AIR DISPERSION MODEL}

\section{Selection}

Two air dispersion/deposition models were investigated for use in this analysis: the Industrial Source Complex Short-term (ISCST3) ${ }^{11}$ and the Fugitive Dust Model (FDM) ${ }^{1}$. ISCST3 is the current EPA-preferred refined air quality model for calculating pollutant concentrations and deposition rates (both wet and dry) at downwind receptors ${ }^{12}$. ISCST3 uses an improved integrated line source algorithm to simulate area sources which has been demonstrated to provide more accurate predictions near a source ${ }^{13}$. However, this integrated line source algorithm requires very long computer computation times. In this analysis, initial area source trial runs using a Pentium 166MHz required greater than 2 minutes/met year/source/receptor. This performance makes it impractical to evaluate the 6 years of meteorological data, 34 area sources, and large numbers of receptors (four grids with approximately 2000 receptors/grid) needed for this assessment.

FDM is considered to be an excellent alternative to ISCST3 for this assessment for the 
following reasons: 1) it was specifically designed for calculating concentration and deposition impacts from fugitive dust sources, 2) it has all the features required for the objectives of this analysis, 3) it has been previously used by EPA to assess particulate emissions in other CERCLA risk assessments ${ }^{14-15}$, and 4) previous model comparisons have shown that it performs as well as or is slightly more conservative than ISCST3 16 . FDM uses either a default integrated 5-line source or a convergent integrated line source algorithm for simulating area sources. The convergent integrated line source is essentially equivalent to the ISCST3 area source algorithm and also requires substantial computer run time. The default 5-line integration algorithm was used in this analysis and required run times of about 0.015 minutes/met year/source/receptor which is less than $1 \%$ of the time required for the ISCST3 area source runs.

FDM has an improved gradient-transfer dry deposition algorithm, evaluates standard preprocessed hourly meteorological data, accounts for site-specific particle size data, and will accept an external hourly emission rate file. Although FDM will evaluate up to 200 sources, it does not provide output on individual source contributions for multiple source runs. Therefore, if individual source contributions are desired, separate runs must be made for each source, and the results must then be manually combined to obtain cumulative impacts from all the sources. For this analysis, a modified version of the model (FDMBOT, 12/5/97) was obtained from the author that evaluates up to 2200 receptors per run. The model provides deposition rate (flux) output in units of $\mu \mathrm{g} \mathrm{m}^{-2} \mathrm{~s}^{-1}$, when the source emission rate is input as $\mathrm{g} \mathrm{m}^{-2} \mathrm{~s}^{-1}$.

\section{Model Input}

\section{$\underline{\text { Model Switches and Options }}$}

The FDM switch selections used in the modeling runs (model input value in parenthesis) were as follows:

- $\quad$ Default 5-line integration area source algorithm used (1)

- $\quad$ Preprocessed meteorological data used (2)

- $\quad$ Plotter files ( $\mathrm{x}, \mathrm{y}, \mathrm{z})$ made for annual average runs (2)

- $\quad$ Meteorological data were not printed (1)

- $\quad$ Model computed hourly deposition and gravitational settling velocities (1)

- Annual averages (4) and the highest two 24-hour concentrations were printed (3) (separate runs)

- Calms recognized by the combination of a wind speed equal to $1.0 \mathrm{~m} / \mathrm{s}$ and a repeated wind direction from the previous hour (1)

- $\quad$ Hourly emission file used (2) 
Area sources are input to FDM as a rectangle defined by a center point, an x-dimension, a $\mathrm{y}$-dimension, a rotation angle, and various other emission parameters. Although the model will evaluate up to 200 sources, minimizing the number of sources significantly reduces model run times. Aerial photos were examined and an on-site inspection was done to define areas within the six major tailings sites that would likely produce the most emissions and to eliminate areas with significant vegetation and/or standing surface water. Narrow, tendril-like arms on some of the tailings sites were eliminated if they were sheltered by forested ridges and there were no residential receptors located nearby. Thirty-three area sources were evaluated in the final modeling (Figure 4).

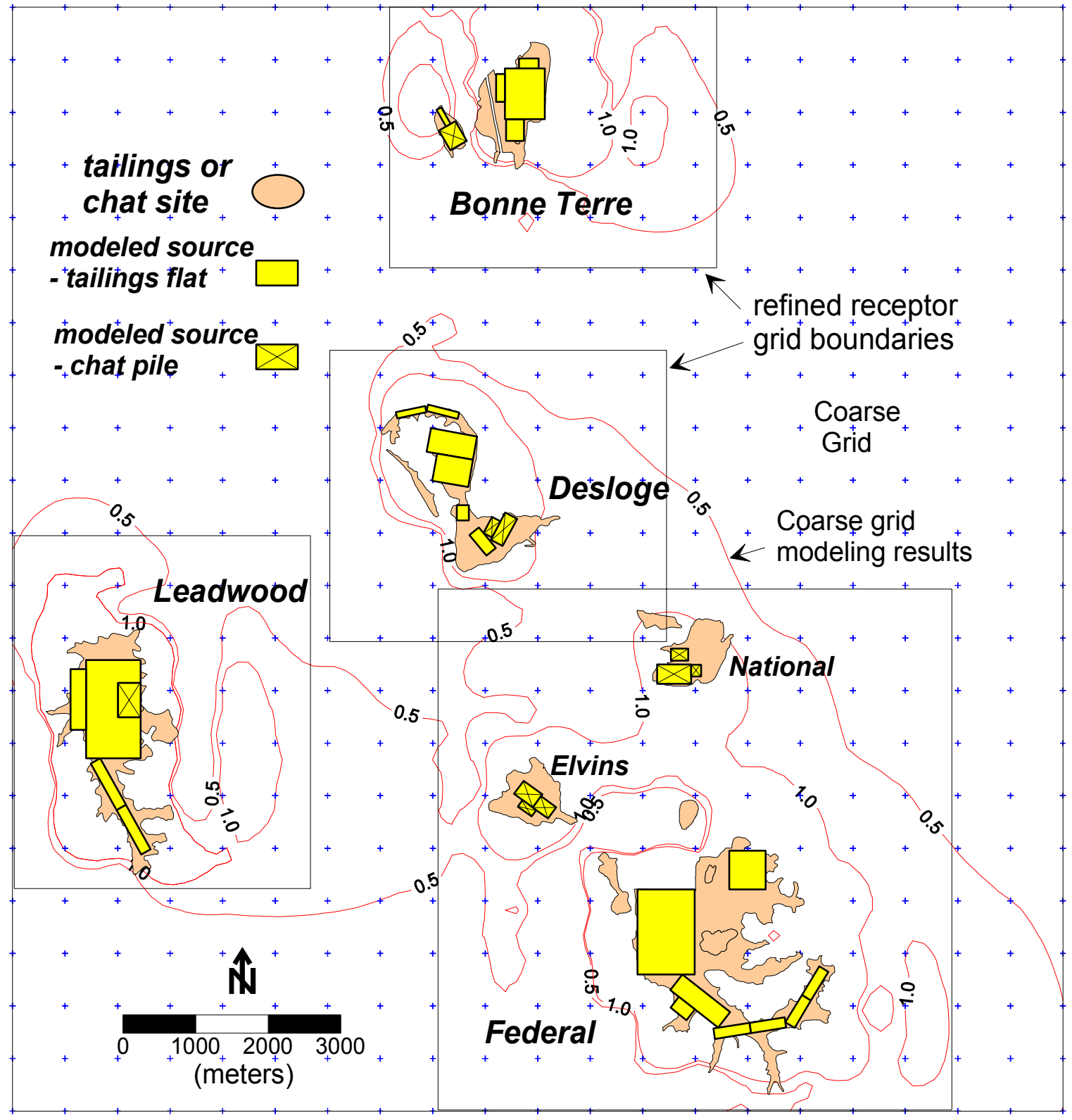

Each modeling run evaluated one of the six major tailings sites as simulated by the area source boxes. The results were then tabulated in a spreadsheet for a given receptor grid, and cumulative impacts at a particular receptor were determined by summing impacts from sources 
that were found to contribute in that particular receptor grid (see Receptor Grid Input).

To account for their elevated release height, the chat piles were simulated as "verticallydistributed" area sources with 9 layers and a maximum height of 20 meters. Although most of the chat piles range in height from 46 to 61 meters, FDM does not have mass-conservation correction factors for heights greater than $20 \mathrm{~m}$, and large errors are possible if higher release heights are input.

Particle size data were taken from AP-42 aerodynamic particle size multipliers for windgenerated particulate emissions from mixtures of erodible and nonerodible surface material subject to disturbance (AP-42, section 13.2.5.3) (Table 3). Site-specific PM-10 and TSP measurements taken over a 15-month period at the Desloge site indicated a PM-10/TSP ratio of 0.53 , which compares favorably with the AP-42 value (0.5) used in this analysis.

Table 3. Particle size data used in the analysis.

\begin{tabular}{c|c|cc}
\hline $\begin{array}{c}\text { Size Range ( } \\
\boldsymbol{\mu m})\end{array}$ & $\begin{array}{c}\text { Midpoint }(\boldsymbol{\mu} \\
\mathbf{m})\end{array}$ & Fraction & Density \\
\hline $0-2.5$ & 1.25 & 0.2 & $1.0^{\mathrm{a}}$ \\
\hline $2.5-10$ & 6.25 & 0.3 & 1.0 \\
\hline $10-15$ & 12.5 & 0.1 & 1.0 \\
\hline $15-30$ & 22.5 & 0.4 & 1.0 \\
\hline
\end{tabular}

a. Appropriate value for aerodynamic particle sizes.

External hourly emission rate files for each source and year of meteorological data were developed from the source emissions model spreadsheet calculations. These files contained hourly emission rates in units of $\mathrm{g} \mathrm{m}^{-2} \mathrm{hr}^{-1}$ for each source which provided FDM deposition rate output in $\mu \mathrm{g} \mathrm{m}^{-2} \mathrm{hr}^{-1}$.

\section{$\underline{\text { Meteorological Data }}$}

Since the objectives of this study were to predict the average annual and maximum 24hour impacts that have occurred in the region over the last 80 years, a meteorological data set was needed that would adequately represent the long-term historical conditions in the region. Although some on-site meteorological data have been taken at the Desloge site, only about 1 year of measurements were available and most of the results were averaged over one-hour time periods, which is too short to calculate the stability class parameter required for the model input file. Typically, 5 years of data from the nearest airport are considered to be adequate for this purpose $^{12}$. This assessment therefore used six years $(1984-85,1987-90)$ of hourly surface data from the St. Louis/Lambert International Airport which is located approximately 60 miles to the north.

The St. Louis meteorological data were obtained from NOAA's National Climatic Data Center in the Solar and Meteorological Surface Observational Network (SAMSON) CD-ROM format. The SAMSON data were also used to obtained the hourly precipitation data that was 
used in the source emissions modeling. Twice daily mixing heights for the same six year period at Monet, MO were obtained from EPA's Support Center for Regulatory Air Models (SCRAM) website (no mixing height data were available for St. Louis). These data were processed into the required FDM input format of sequential hourly wind direction, wind speed, temperature, stability class, and mixing height using the PCRAMMET (version 95300) program 17. PCRAMMET processes a maximum of 1 year of SAMSON data per run. Therefore, six separate meteorological input files were developed to evaluate the six years of data.

For air modeling input, surface roughness length was assumed to range from $7.5 \mathrm{~cm}$ (farmland) for the upper-bound modeling runs to $75 \mathrm{~cm}$ (small towns, densely wooded) for the lower-bound modeling runs ${ }^{1}$. The value selected for this parameter for use in FDM is higher than that used in the particulate emissions model $(0.002$ to $0.1 \mathrm{~cm})$ because it should represent the larger scale roughness conditions simulated by the model for regional dispersion.

\section{$\underline{\text { Receptor Grids }}$}

Initial modeling runs were made using a single coarse (300-m interval) receptor grid that covered the entire region to determine general dispersion trends, define refined grids around the sources, and identify which sources contribute appreciably in each refined grid. Results from these runs indicated that four refined grids would be required (Figure 3). To improve the spatial resolution of the model results, a modified version of FDM was obtained from the author that evaluates up to 2200 receptors. This allowed refined grid spacings of $100 \mathrm{~m}$ to $150 \mathrm{~m}$ (Federal grid). Existing residential receptors in two of these grids (Bonne Terre and Leadwood) were primarily impacted only by sources within those grids, while the remaining sources (Desloge, National, Elvins, and Federal sites) impacted residential receptors in both the Desloge and Federal grids. Therefore, 11 source/receptor grid combinations were evaluated which required a total of 66 FDM runs to evaluate the 6 years of meteorological data (Table 4)

FDM assumes the source and the receptor are at the same elevation and does not evaluate "complex terrain" affects. Although these affects can be very important for elevated (e.g. stack) releases, they are not as important for fugitive dust releases which are generally at ground-level. Hills and valleys can certainly channel flow of ground-level dust plumes, but these cannot generally be modeled without data from multiple met stations in the area to provide a wind field. More importantly, this assessment was done primarily to evaluate impacts in communities adjacent to the sources, most of which are not significantly affected by terrain.

\section{$\underline{\text { Post-Processing }}$}

The large numbers of FDM runs made to evaluate the 11 source/receptor grid combinations, 6 years of meteorological data, different averaging times (24-hour and annual), and upper- and lower-bound emission rates required significant post-processing to obtain cumulative impacts for contour plotting. This post-processing was accomplished by "pasting" FDM output into custom spreadsheets which summed deposition rates from the applicable sources by receptor for each year of results and then averaged the six 1-year results. A final (x, $\mathrm{y}, \mathrm{z}$ ) data file for each receptor grid was then obtained and plotted using contouring software for the following cases (all units are in $\mu \mathrm{g} \mathrm{m}^{-2} \mathrm{hr}^{-1}$ ): 
1) Annual average deposition rates - low bound emission rates

2) Annual average deposition rates - high bound emission rates

3) Maximum 24-hour deposition rates - low bound emission rates

4) Maximum 24-hour deposition rates - high bound emission rates

Table 4. Source-receptor grid combinations evaluated in the modeling.

\begin{tabular}{|c|c|c|}
\hline $\begin{array}{c}\text { Refined } \\
\text { Receptor Grid } \\
\end{array}$ & $\begin{array}{c}\text { Contributing } \\
\text { Sources } \\
\end{array}$ & $\begin{array}{l}\text { Model Input } \\
\text { File Names } \\
\end{array}$ \\
\hline Bonne Terre (B) & $\begin{array}{l}\text { Bonne Terre tailings (BTT) } \\
\text { Bonne Terre chat (BTC) }\end{array}$ & $\begin{array}{l}\text { BTT84 - ВTT90а } \\
\text { ВTC84 - ВTC90 }\end{array}$ \\
\hline Desloge (D) & $\begin{array}{l}\text { Desloge tailings (DT) } \\
\text { Desloge chat (DC) } \\
\text { National chat (NAT) } \\
\text { Elvins chat (EC) }\end{array}$ & $\begin{array}{l}\text { DDT84 - DDT90 } \\
\text { DDC84 - DDC90 } \\
\text { DNAT84 - DNAT90 } \\
\text { DEC84 - DEC90 }\end{array}$ \\
\hline Federal $(\mathrm{F})$ & $\begin{array}{l}\text { Federal tailings (FT) } \\
\text { National chat (NAT) } \\
\text { Elvins chat (EC) }\end{array}$ & $\begin{array}{l}\text { FFT84 - FFT90 } \\
\text { FNAT84 - FNAT90 } \\
\text { FEC84 - FEC90 }\end{array}$ \\
\hline Leadwood (L) & $\begin{array}{l}\text { Leadwood tailings (LC) } \\
\text { Leadwood chat (LT) }\end{array}$ & $\begin{array}{l}\text { LT84 - LT90 } \\
\text { LC84 - LC90 }\end{array}$ \\
\hline
\end{tabular}

a. Six FDM input files were required to evaluate the six 1-year meteorological input files (1984-85, 1987-90).

\section{CONVERSION OF DEPOSITION RATE TO SOIL CONCENTRATION}

Modeled deposition rates ( $\mu \mathrm{g} \mathrm{m}^{-2} \mathrm{hr}^{-1}$ ) were converted to estimated soil concentrations $\left(\mathrm{mg} \mathrm{kg}^{-1}\right)$ using the following assumptions:

- The wind erosion potential of the vegetated downwind receptor locations is much smaller than the highly erodible tailings sources. Therefore, wind resuspension loss rates at downwind receptors are considered to be insignificant compared to deposition rates at these locations.

- Long-term deposition rates have been approximately uniform since the tailings sources came into existence (approximately 80 years ago). The source has had "unlimited" erosion potential during the time period of interest.

- All of the deposited lead is assumed to be contained within $5.08 \mathrm{~cm}$ of the surface (2-inch sampling depth) based on studies which have shown insignificant downward transport of the tailings in soil. This assumption would not apply in areas where the surface soil could have been mixed to a deeper depth or horizontally transported, which would include: 1) farmed areas that have been tilled, 2) developed areas that have been excavated or landscaped, and 3 ) areas that may have been subjected to flood.

Using the above assumptions, downwind receptor locations can be assumed to act as a 
"sink" for the deposited lead, and the predicted soil lead concentrations $\left[\mathrm{C}(80)\right.$ in $\left.\mathrm{mg} \mathrm{kg}^{-1}\right]$ can be calculated as:

$\begin{array}{ll}\text { where } & \mathrm{R}_{\mathrm{in}}=\text { predicted annual average deposition rate }\left(\mathrm{mg} \mathrm{kg}^{-1} \mathrm{y}^{-1}\right) \\ & \mathrm{C}_{\mathrm{b}}=\text { lead background concentration in soil }\left(65 \mathrm{mg} \mathrm{kg}^{-1}\right)\end{array}$

The value for $\mathrm{R}_{\text {in }}$ was calculated from the model areal deposition rate results

(in $\mu \mathrm{g} \mathrm{m}^{-2} \mathrm{hr}^{-1}$ ) and assumptions for mixing depth (5.08 $\mathrm{cm}$ sampling depth) and tailings bulk density $\left(1.6 \mathrm{~g} \mathrm{~cm}^{-3}\right)$ by:

Although the "sink" compartment model assumption implicit in equation (8) does not account for the fact that the downwind soil concentrations would never exceed those at the source, they are adequate for the time period of interest (the receptor concentrations calculated using the above methods were much less than the source concentrations).

Based on comparisons between model predicted soil concentrations and those evaluated from soil sampling at one of the sites (see following section), a single conservative "bestestimate" soil concentration was calculated using the geometric mean of the low and high bound deposition rate results. The geometric mean was used, not necessarily to represent the distribution of modeling results, but because it resulted in the best (closest to 1) model predictedto-observed ( $\mathrm{P} / \mathrm{O})$ ratios for all sampling points.

\section{EVALUATION OF MODEL PERFORMANCE}

\section{Air Concentrations}

Daily (24-hour averaged) air monitoring data for lead were available for an 18-month period from four air samplers located adjacent to the Desloge site (Figure 5) ${ }^{b}$. FDM model runs were made to calculate long-term average and maximum 24-hour lead air concentrations at the sampler locations using the source emissions model developed in this assessment and the results were plotted together for comparison.

Initial attempts made to "back-calculate" source emission rates during this period using the air monitoring data and Desloge on-site meteorological data were unsuccessful because a critical meteorological input parameter (stability class) could not be determined from the 1-hour averaged meteorological data and several large gaps existed in the data.

. Location of TSP/lead air samplers at the Desloge site. 


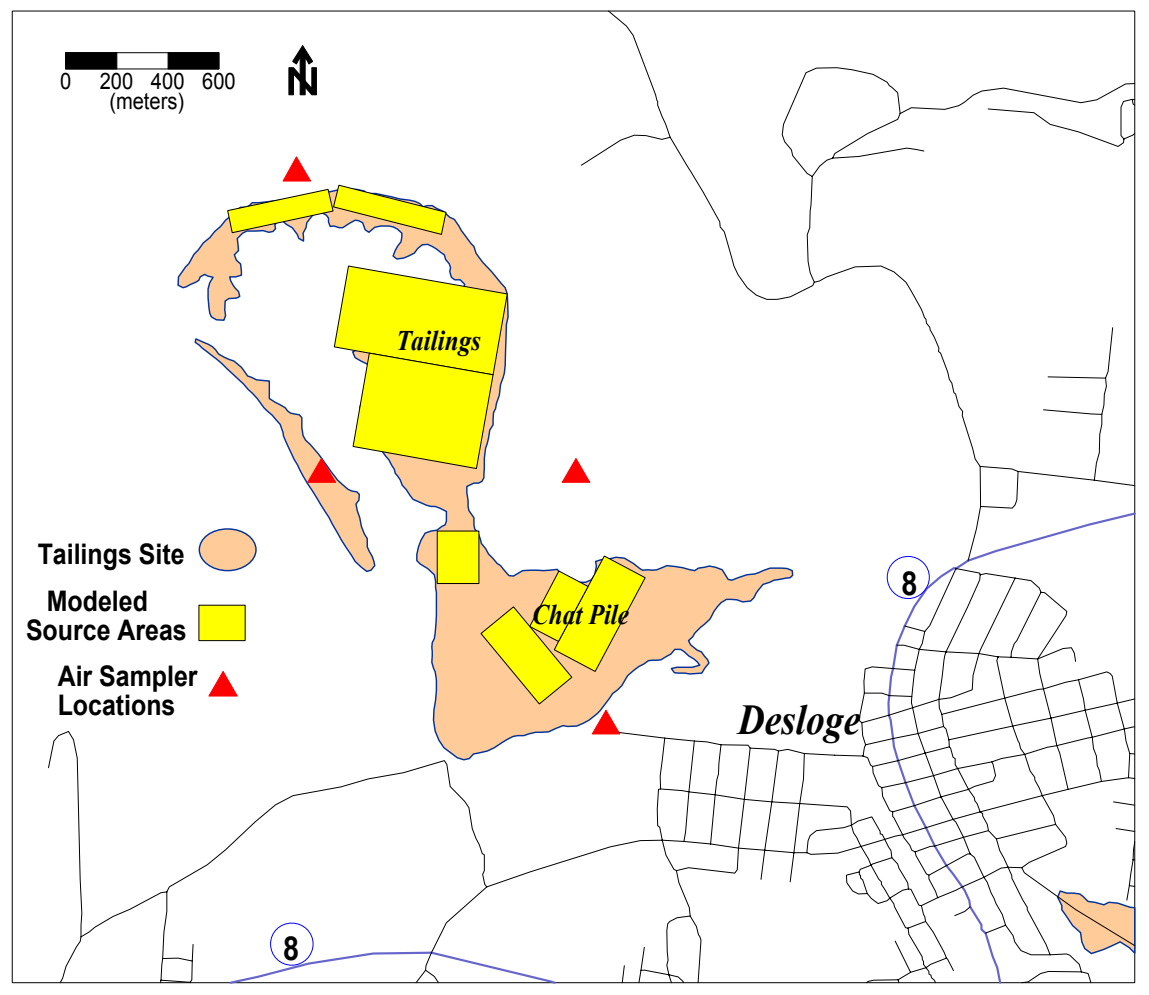

\section{Soil Concentrations}

Modeled deposition rate isopleths $\left(\mu \mathrm{g} \mathrm{m}^{-2} \mathrm{hr}^{-1}\right)$ were used to determine the best locations for soil samples around the Bonne Terre site (Figure 6). A soil sampling transect was laid out in the area of maximum modeled impacts east of site, and 17 surface $(0-5.08 \mathrm{~cm})$ soil samples were taken at 100-m intervals and analyzed for lead. The sampling results were then compared to predicted soil concentrations which were calculated using the upper- and lower-bound and geometric mean of the lower- and upper-bound modeled deposition rates at the sampling locations and equation (8). The geometric mean was used, not necessarily to represent the distribution of modeling results, but rather because it resulted in the best (closest to 1) predicted- to-observed $(\mathrm{P} / \mathrm{O})$ ratio for all sampling points.

- Soil sampling locations and modeled deposition rate isopleths (g m 


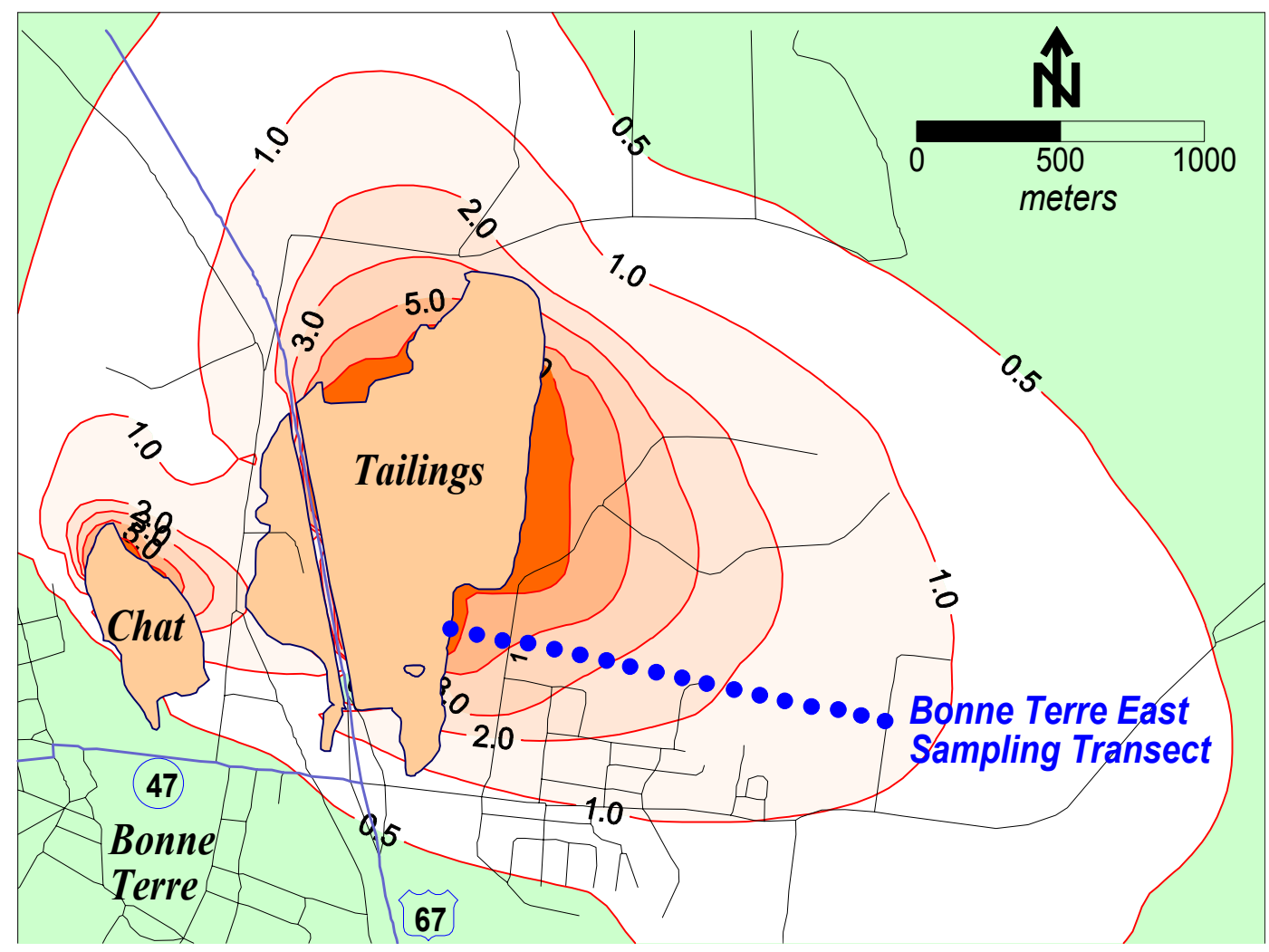




\section{RESULTS AND DISCUSSION}

\section{Deposition Rates}

For all sites, the highest modeled deposition rates occurred to the east-southeast of each site, with a secondary impact area to the north. Since a single meteorological file was used for all modeling, the directions of maximum impacts (general shapes of the deposition footprints) were the same for all sites. In general, annual average deposition rates within $200 \mathrm{~m}$ of the tailings site boundaries ranged from $5 \mu \mathrm{g} \mathrm{m} \mathrm{m}^{-2} \mathrm{hr}^{-1}$ (low-bound) to $100 \mu \mathrm{g} \mathrm{m}^{-2} \mathrm{hr}^{-1}$ (high-bound). At $1 \mathrm{~km}$ from the tailings sites in the east-southeasterly direction of maximum impacts, annual average deposition rates ranged from $1 \mu \mathrm{g} \mathrm{m}^{-2} \mathrm{hr}^{-1}$ to $30 \mu \mathrm{g} \mathrm{m}^{-2} \mathrm{hr}^{-1}$. The Bonne Terre tailings site produced the highest deposition rates, although there is relatively little development east of the site. These higher impacts are likely due to the higher lead concentrations at this source. The chat piles (Bonne Terre, National, and Elvins) produced much lower deposition rates, even though they have higher lead concentrations than the tailings sites. This was likely due to their larger particle sizes, higher threshold friction velocities, and the resulting lower suspension rates. Maximum 24-hour deposition rates followed the same pattern as the annual average results but with much higher values (e.g. much greater than $1000 \mu \mathrm{g} \mathrm{m}^{-2}$ $\mathrm{hr}^{-1}$ near the sites and from 60 to $1000 \mu \mathrm{g} \mathrm{m}^{-2} \mathrm{hr}^{-1}$ at $1 \mathrm{~km}$ ). Lower- and upper-bound deposition rate results $\left(\mu \mathrm{g} \mathrm{m}^{-2} \mathrm{hr}^{-1}\right)$ around each of the six sites are included in Appendix A.

\section{Soil Concentrations}

Based on comparisons of model-predicted to sampling-observed ratios (subsequent section), best-estimates of undisturbed soil concentrations were calculated from the geometric mean of the lower- and upper-bound deposition rates around each of the sites (Figures 7 through 10). The geometric mean was used not to represent a valid statistical mean, but because it fit the sampling results very well (see Table 5). Concentrations range from about 300 to $500 \mathrm{mg} \mathrm{kg}^{-1}$ within about $200 \mathrm{~m}$ of the tailings site boundaries and from about 125 to $175 \mathrm{mg} \mathrm{kg}^{-1}$ at $1 \mathrm{~km}$. Upper-bound estimates of soil concentrations are about a factor of 2 higher than the best-estimate values, and lower bound estimates are about $1 / 2$ the best-estimate values.

It is emphasized that these soil concentration results apply only to generally undisturbed surface soils which have not been subjected to significant tillage, excavation, landscaping, or flooding. In addition, the calculated concentrations assume that all of the lead deposition remains essentially on the surface but is subsequently mixed within a 5.08-cm (2-inches) sampling depth. The concentrations will therefore vary with the depth of integration in the soil profile, i.e., samples taken from 0 to $2.54 \mathrm{~cm}$ would have higher concentrations than those calculated here using the 0 to $5.08 \mathrm{~cm}$ sampling depth. Aerodynamic effects of buildings or other topographic features (discussed below) would also affect field measured concentrations. 
Figure 7. Predicted lead concentrations in undisturbed surface soils ( $\mathrm{mg} \mathrm{kg}$

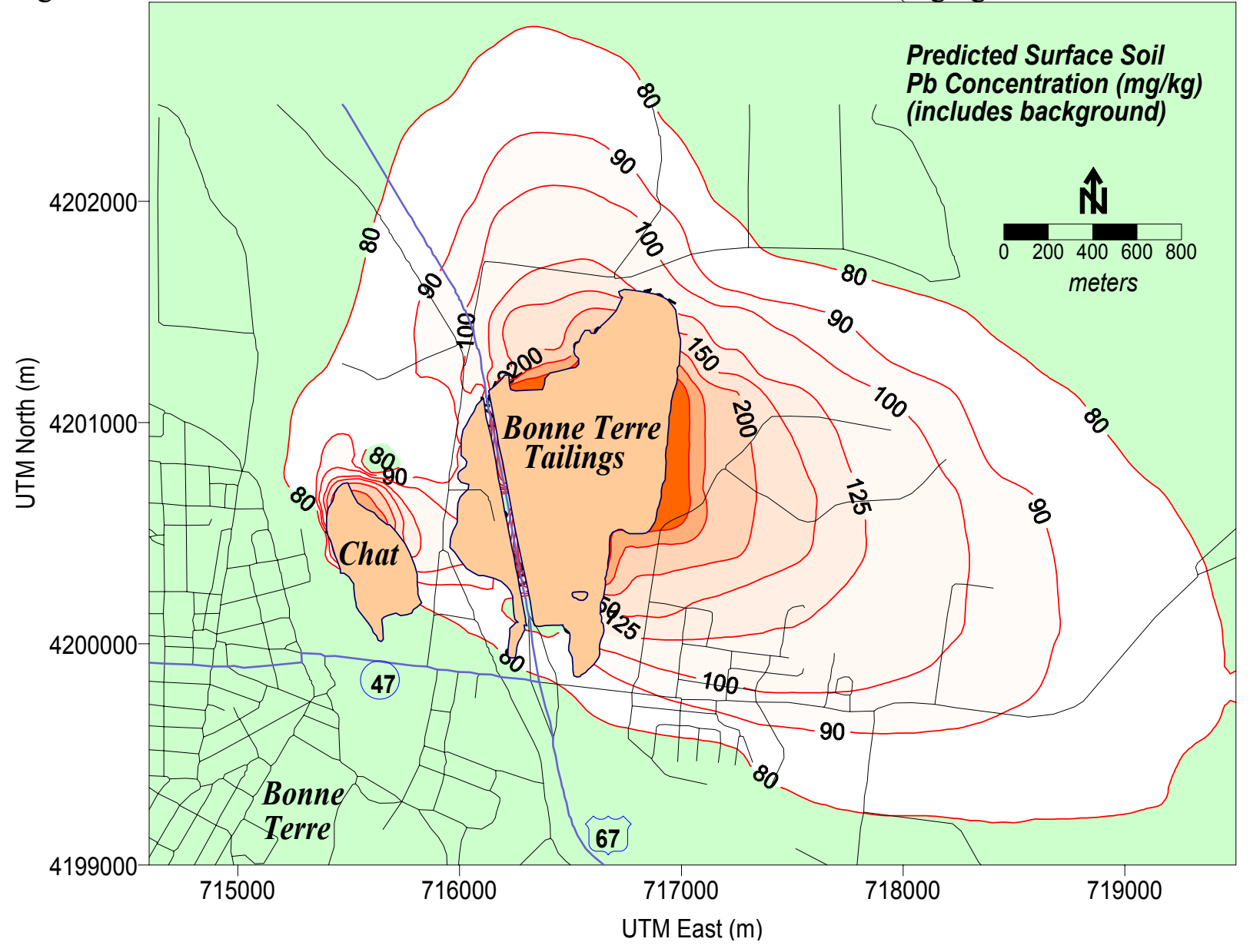


Figure 8. Predicted lead concentrations in undisturbed surface soils (mg

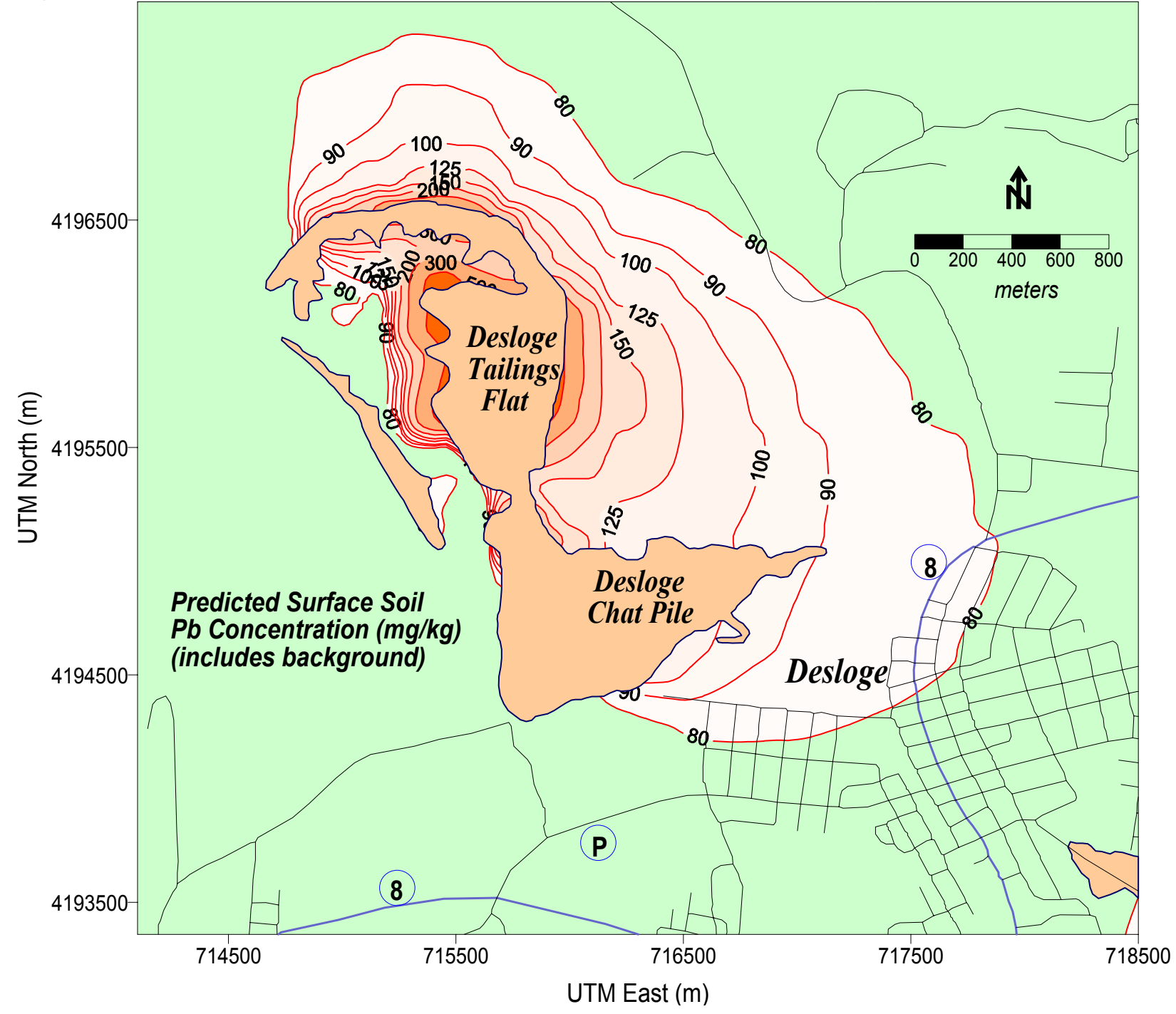


Figure 9. Predicted lead concentrations in undisturbed surface soils (mgs.

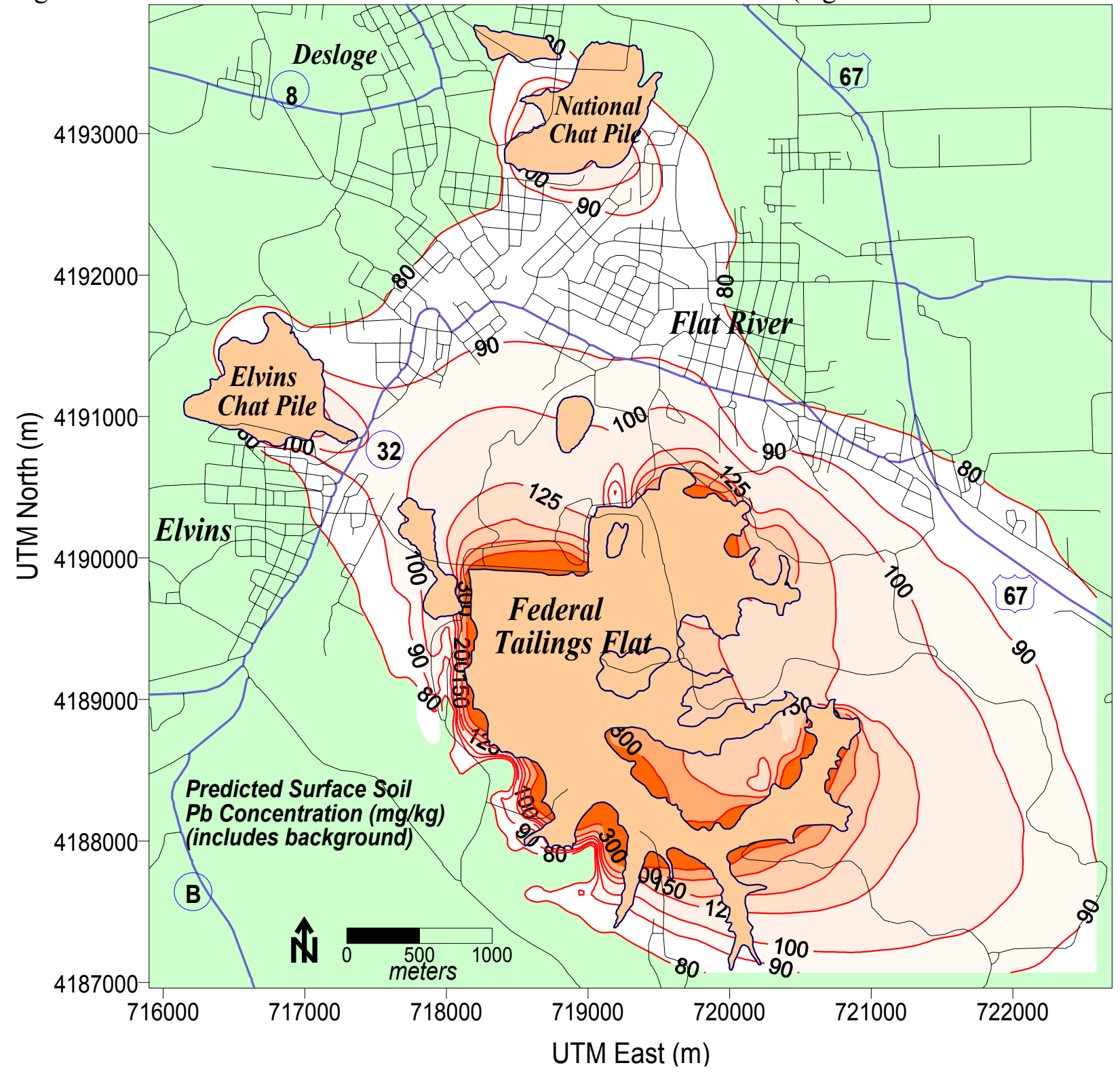


Figure 10. Predicted lead concentrations in undisturbed surface soils (mg

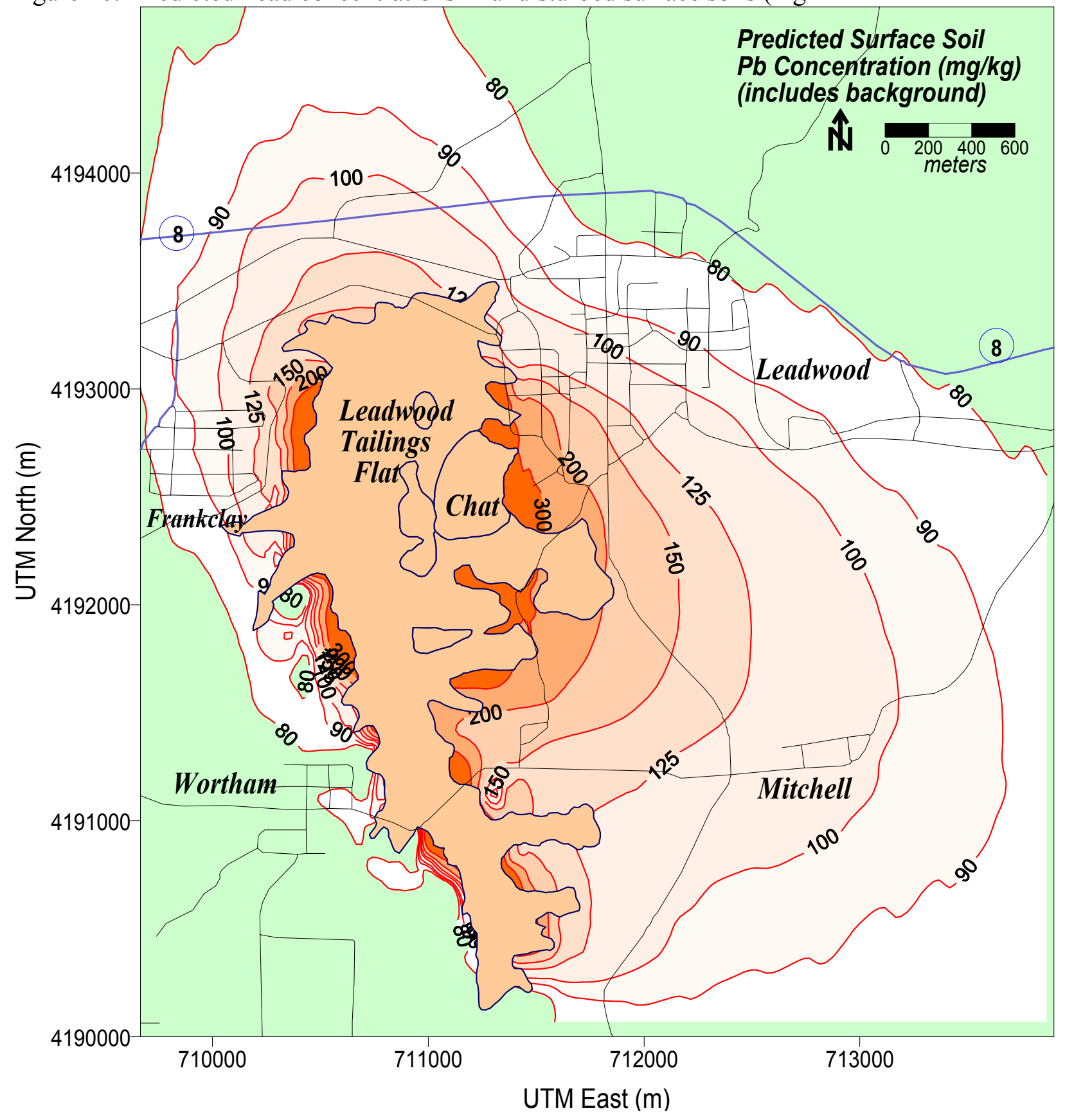




\section{Effects of Buildings and Obstacles on Deposition Rate}

In developed areas, downwind deposition rates and the resulting soil concentrations may be significantly influenced by 1) the aerodynamic affects of buildings or other obstacles on wind flow patterns adjacent to these structures and 2) potential local sources of lead (e.g. lead paint from buildings) which may obscure the contribution from tailings fallout. Wind flows around buildings are known to produce turbulent "downwash" effects which can increase ground-level air concentrations on the lee side of a building by factors of two to five over the no-building values (flat ground) ${ }^{19}$. On the windward side of buildings, rising flow can divert pollutants upward and therefore may result in reduced air concentrations immediately in front of the building. Deposition rates around obstacles follow this same pattern, similar to that observed on the lee and windward sides of a snow fence.

The area downwind of a building that produces maximum downwash is known as the recirculating "cavity" zone. The size and shape of this zone are primarily a function of the building shape and dimensions: L (along wind direction), W (crosswind direction), and $\mathrm{H}$ (height) relative to the wind direction. For cubes, Yang and Meroney (1970) found a cavity length between $3 \mathrm{H}$ and $4 \mathrm{H}$, measured from the upwind face. Other wind tunnel studies report cavity length ranging from $1 \mathrm{H}$ to $2 \mathrm{H}$ measured from the lee face of the cube. Wider buildings increase the length of the cavity zone. For a typical building ( $\mathrm{L} / \mathrm{H}=0.75$; W/H from 1 to 5 ), the cavity length may extend from about $2 \mathrm{H}$ to $6 \mathrm{H}$, measured from the upwind face. Although the direction of the cavity zone will change depending on the wind direction, the cavity zones of interest for tailings/chat deposition will likely extend in the east-southeasterly and northerly directions from the building, as indicated by the soil concentration isopleths in Figures 7 through 10. The low soil concentrations to the west and south of the sources indicates relatively low wind speeds and a low potential for tailings transport and cavity zone formation in these directions. This spatial variation of soil lead concentrations along source-building direction axes (source to the west or south of the sampling location, cavity zones to the east or north of the building) should also provide good evidence that the source of soil lead is from a tailings/chat site rather than from the building itself (e.g. lead paint).

\section{Comparisons of Modeling Results to Sampling Data}

\section{$\underline{\text { Air Concentrations }}$}

Model predicted and sampler-measured air concentrations near the Desloge site are shown in Figures 11 through 14. Annual-average comparisons can be made by comparing the long-term average of the measured 24-hour values with the lower- and upper-bound annual average modeling results. Maximum 24-hour comparisons can be made by comparing the highest measured 24-hour value with the lower- and upper-bound maximum 24-hour modeled results. The following observations can be made:

North Sampler: Annual average modeling results show reasonably good agreement with the average of the measured values, although the modeled results are slightly low. Model-predicted to observed $(\mathrm{P} / \mathrm{O})$ ratios range from 0.11 to 1.3 . The maximum measured 24-hour values fall within the lower- and upper-bound modeled values. The somewhat low model predictions at this sampler may be due to the relatively close location of the sampler to the tailings sources and vehicle traffic on a tailings perimeter road, which was not assessed in the modeling (Figure 15). 
South Sampler: Annual average modeling results underpredicted measured values, with $\mathrm{P} / \mathrm{O}$ ratios of 0.04 to 0.6 . The maximum measured 24-hour values fall within the lower- and upperbound modeled values. The lower annual P/O ratios are likely the result of increased emissions from tailings excavations operations which were occurring due north of the sampler (on the chat pile) during the sampling period.

East Sampler: Annual average modeling results show good agreement with the measured values, with $\mathrm{P} / \mathrm{O}$ ratios ranging from 0.24 to 4.3 . This better performance is likely due to the increased distance (approximately $400 \mathrm{~m}$ ) between the tailings sources and the sampler location. Also, vehicle-suspended dust from the tailings perimeter road (which was not evaluated in the modeling) is more likely to have settled out prior to reaching the sampler.

West Sampler: The model performed least well at this location, with annual average P/O ratios ranging from 0.013 to 0.13 . In addition, several of the measured 24-hour values exceeded the upper-bound maximum 24-hour average modeling results. Some of the possible reasons for this underprediction include 1) the lack of a modeling source for the narrow strip of tailings on which the sampler is located (Figure 15) and 2) the very low meteorological dispersion to west of all sources that was predicted by the model. This latter reason may be due to differences between site-specific meteorological conditions(wind direction and speeds) in this region and the St. Louis airport data used in the modeling. 
Figure 11. Comparison of lowerNorth air sampler at the Desloge tailings site.

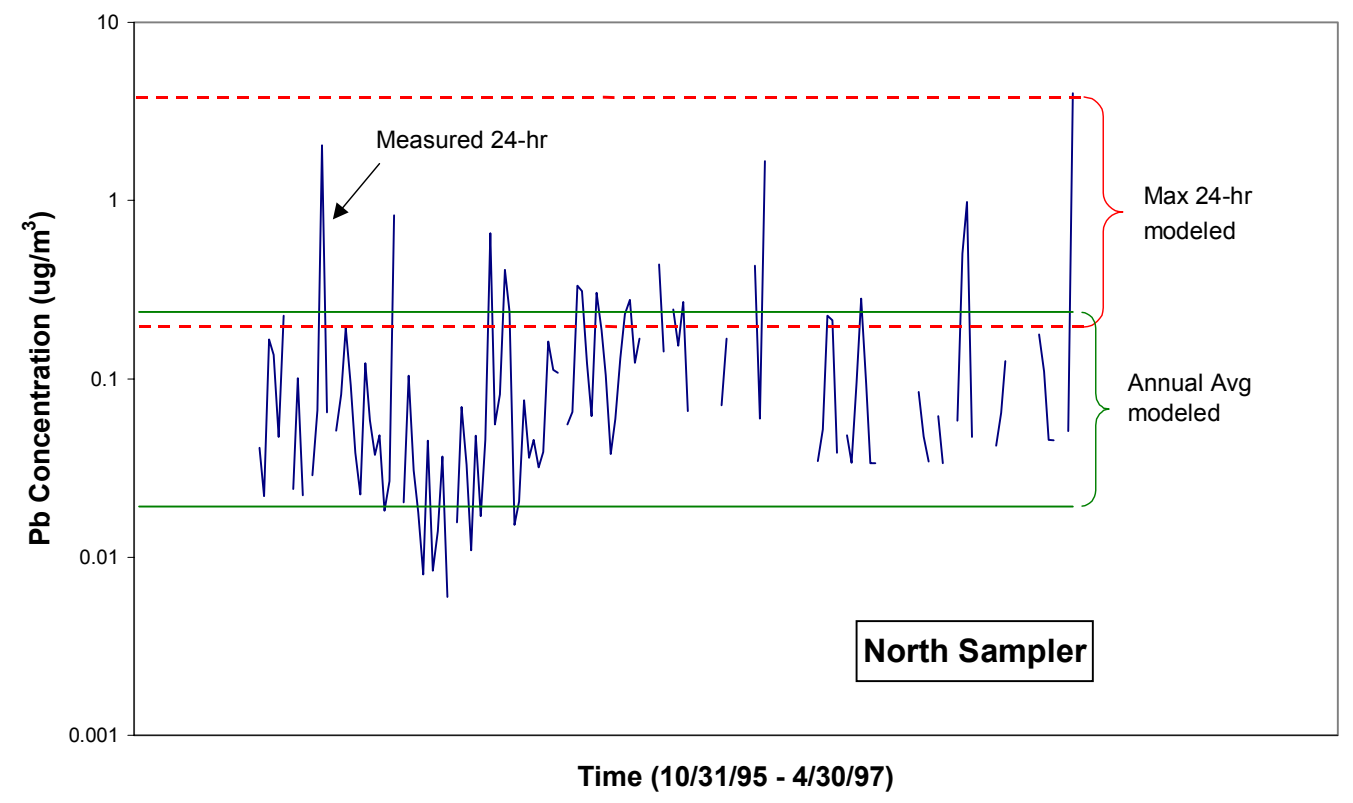

Figure 12. Comparison of lowerSouth air sampler at the Desloge tailings site.

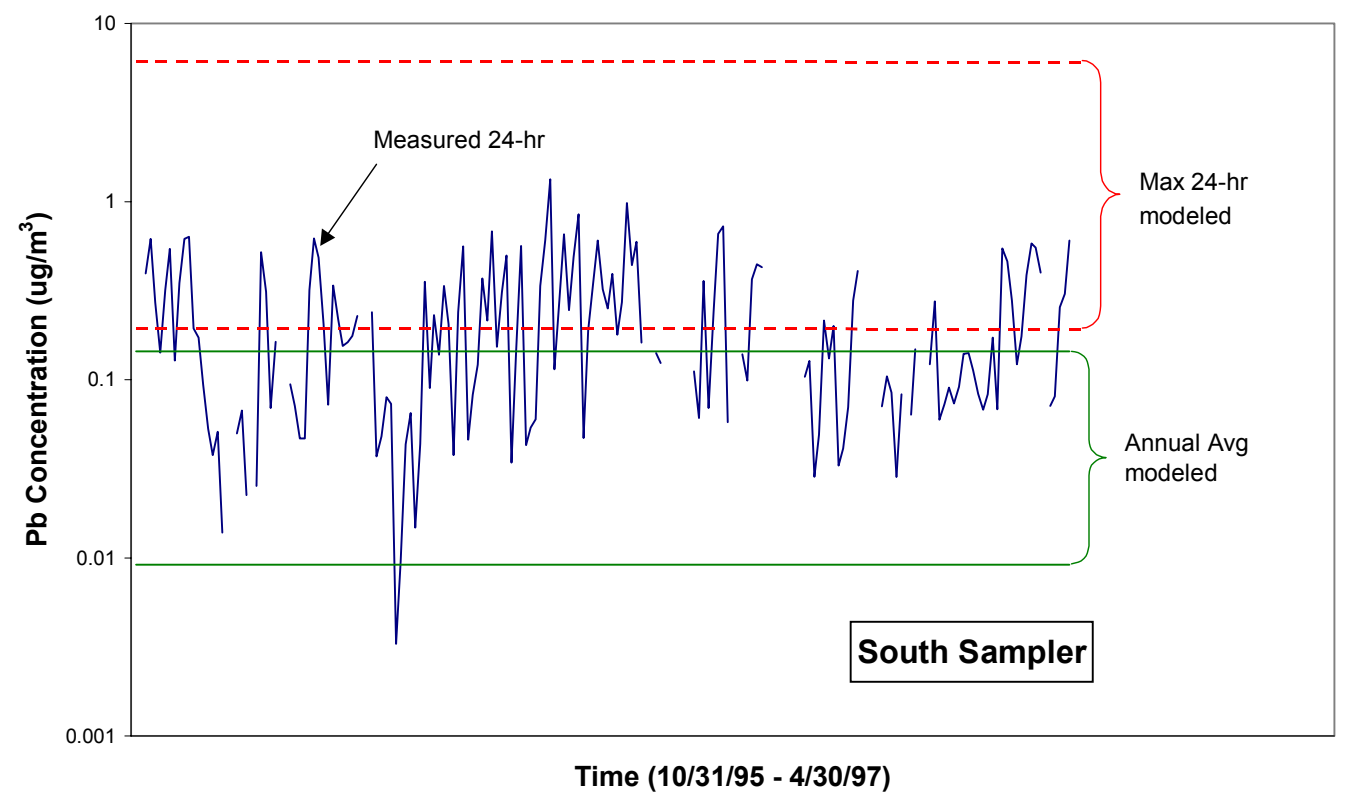


Figure 13. Comparison of lowerEast air sampler at the Desloge tailings site.

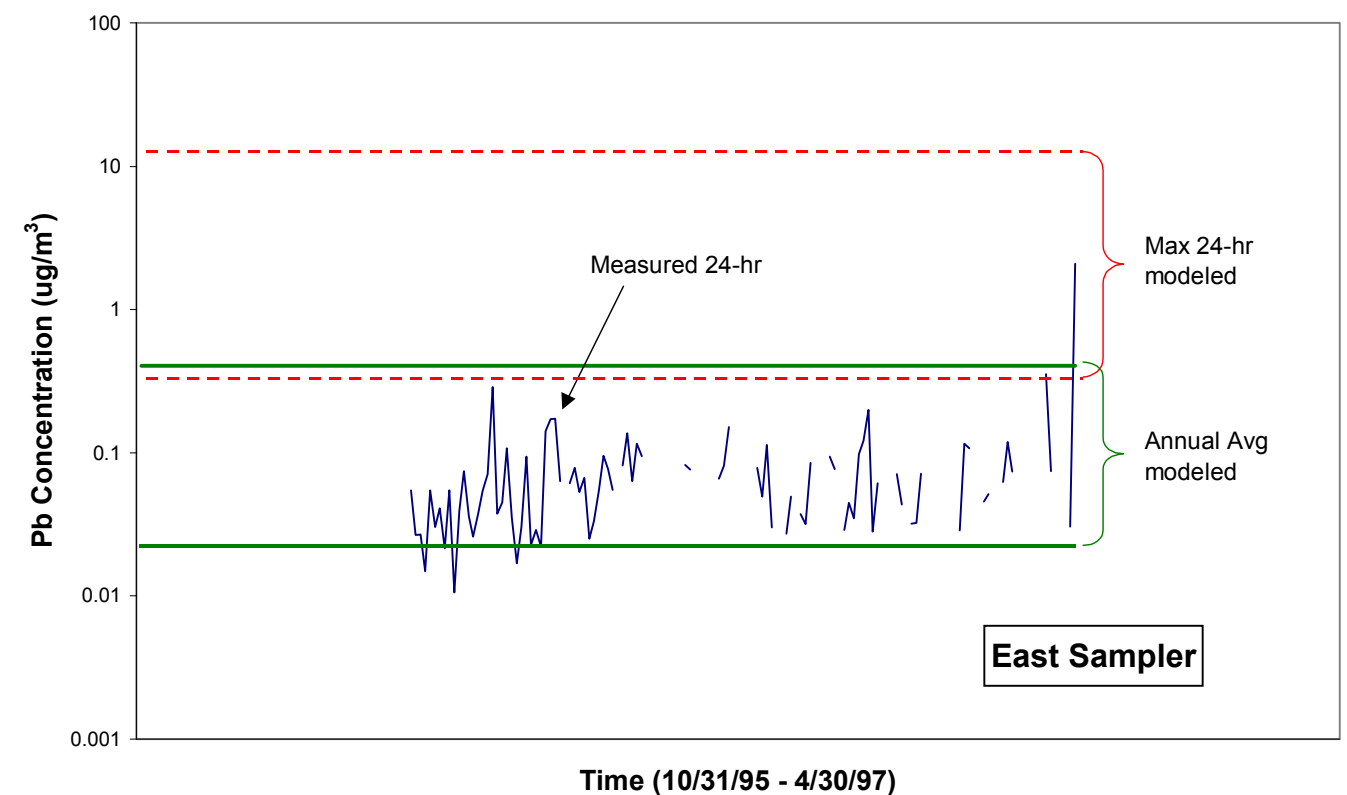

Figure 14. Comparison of lowerWest air sampler at the Desloge tailings site.

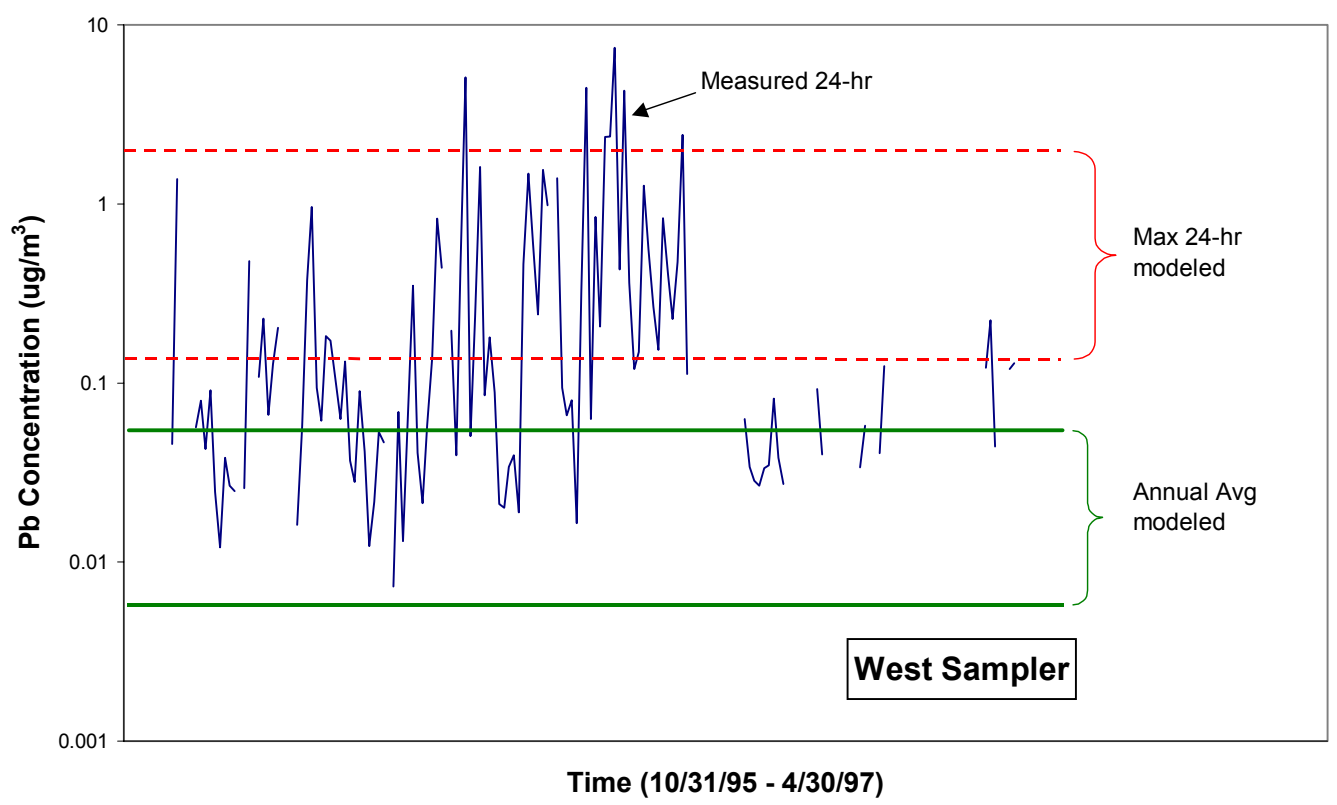


5. Model predictedte air samplers.

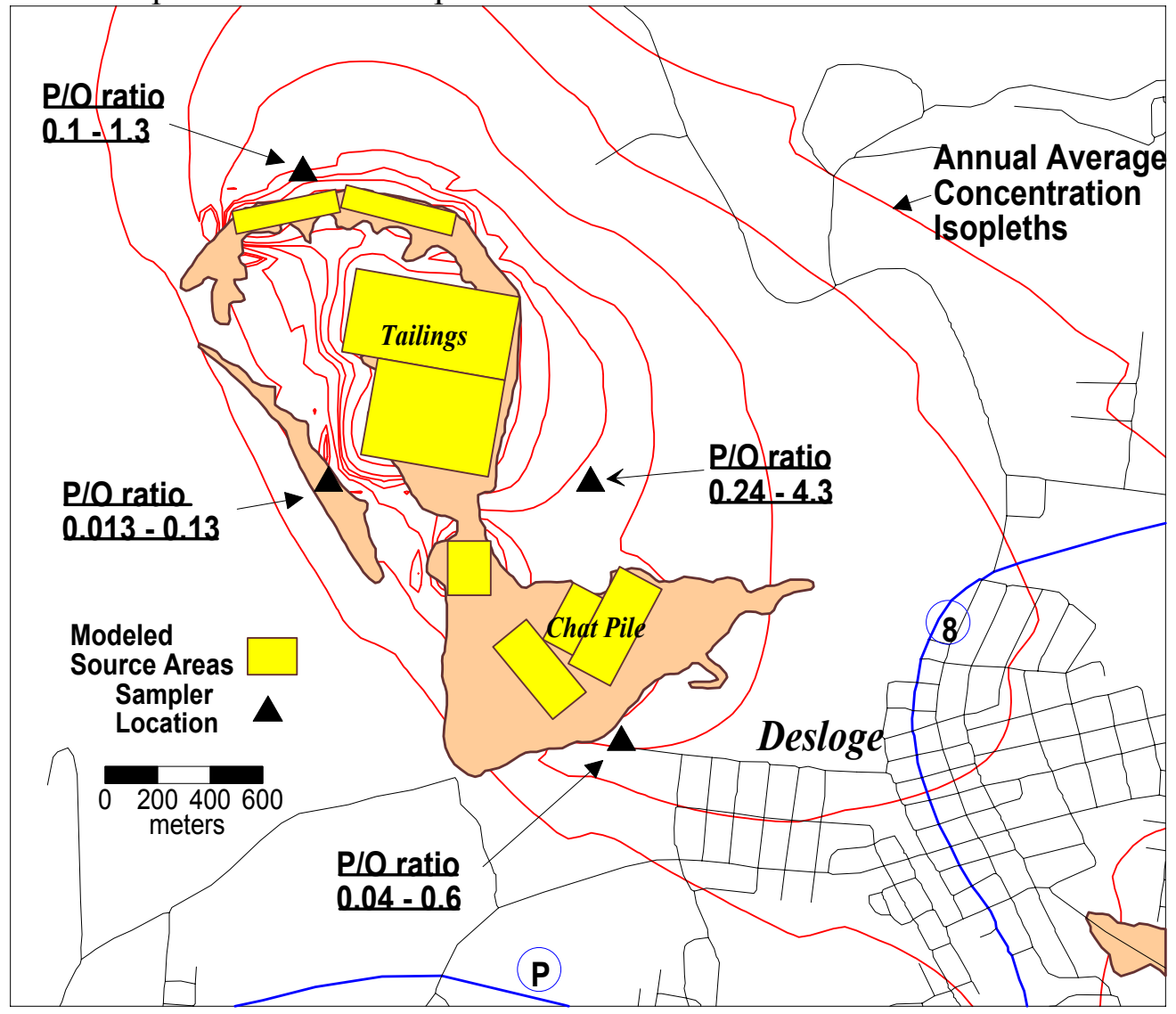

\section{$\underline{\text { Soil Concentrations }}$}

Comparisons of model predicted soil concentrations and those measured along the Bonne Terre East sampling transect (Figure 6) are shown in Figure 16 and Table 5. The predicted concentrations were calculated using the lower-bound, upper-bound, and geometric mean (Gmean in Table 5) of the lower- and upper-bound modeled deposition rates and equation (8) which assumes a sink compartment, 80 years of deposition in a relatively undisturbed area, and a 0 to $5.08-\mathrm{cm}$ surface soil mixing depth. The geometric mean was used, not necessarily to represent the distribution of modeling results, but rather because it resulted in the best (closest to 1) $\mathrm{P} / \mathrm{O}$ ratio for all sampling points. $\mathrm{P} / \mathrm{O}$ ratios averaged over all samples ranged from 0.56 , calculated using the low-bound modeled deposition rates, to 2.1, calculated using the high-bound deposition rates. The $\mathrm{P} / \mathrm{O}$ ratios calculated using the geometric mean of the lower- and upperbound modeled concentrations ranged from a low of 0.84 at $300 \mathrm{~m}$ to a high of 1.4 at $1800 \mathrm{~m}$, with an average of 1.1. The $\mathrm{P} / \mathrm{O}$ ratios tend to increase slightly at distances beyond about $1 \mathrm{~km}$. These $\mathrm{P} / \mathrm{O}$ ratios demonstrate exceptional model performance for the particular sampling transect (location and direction) evaluated.

6. Comparison of measured soil concentrations at the Bonne

Terre tailings site with those calculated using modeled deposition rates. 


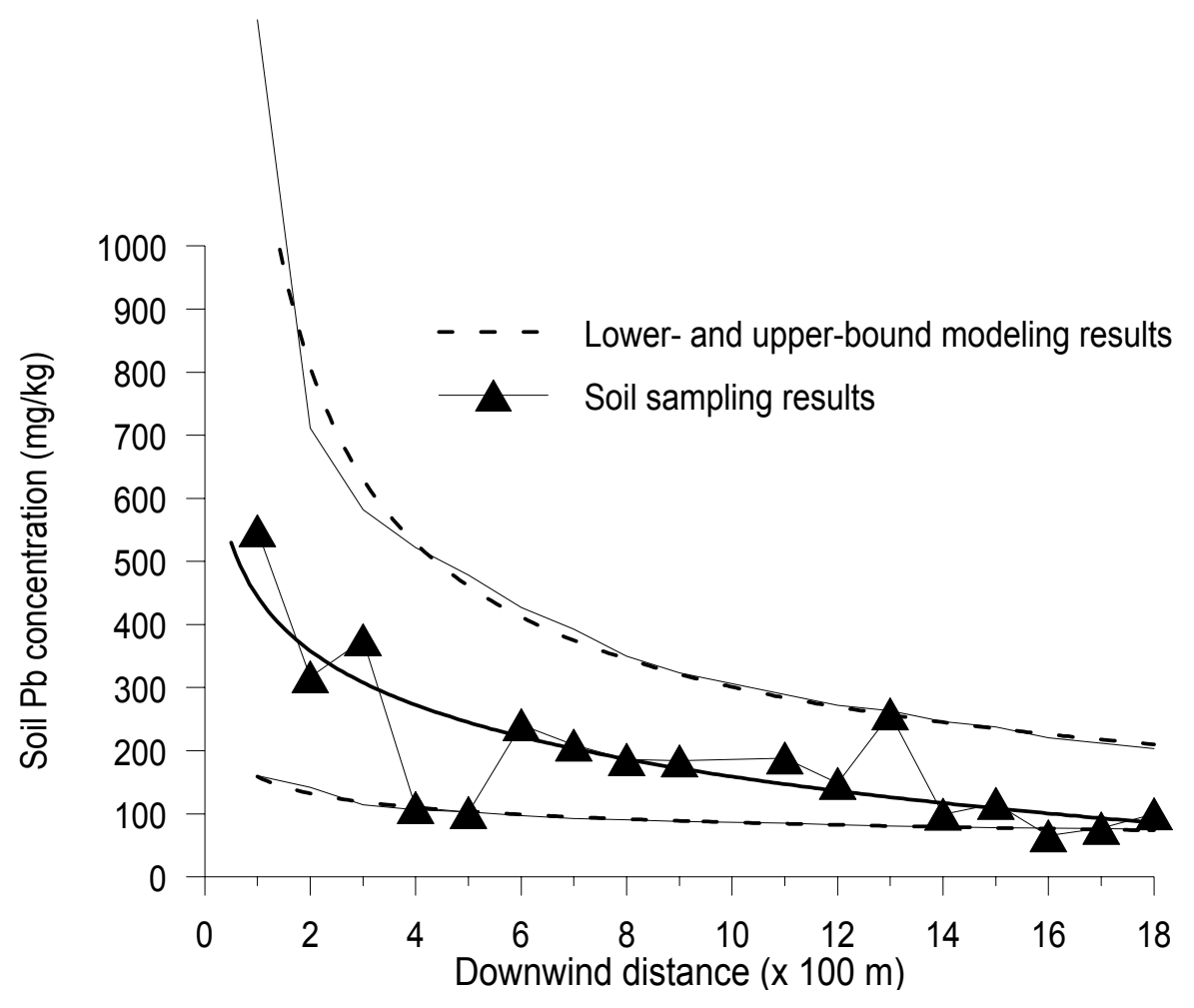

Table 5. Comparison of modeled and measured soil concentrations along the Bonne Terre East sampling transect. 


\begin{tabular}{|c|c|c|c|c|c|c|c|c|}
\hline \multirow{3}{*}{$\begin{array}{c}\text { Downwin } \\
\text { d } \\
\text { Distance } \\
\text { (x 100 m) }\end{array}$} & \multicolumn{5}{|c|}{ Soil Concentration (mg kg-1) } & \multicolumn{3}{|c|}{ P/O Ratio } \\
\hline & \multicolumn{3}{|c|}{ Modeled } & \multicolumn{2}{|c|}{ Measured } & \multirow[b]{2}{*}{ Low } & \multirow[b]{2}{*}{ High } & \multirow[b]{2}{*}{$\underset{n}{G m e a}$} \\
\hline & Low & High & Gmean & Sample & $\begin{array}{c}\text { Regresse } \\
\text { d }\end{array}$ & & & \\
\hline 1 & 160 & 1359 & 466 & 549 & 444 & 0.36 & 3.1 & 1.1 \\
\hline 2 & 142 & 712 & 318 & 317 & 358 & 0.40 & 2.0 & 0.89 \\
\hline 3 & 114 & 582 & 258 & 376 & 308 & 0.37 & 1.9 & 0.84 \\
\hline 4 & 106 & 522 & 236 & 110 & 272 & 0.39 & 1.9 & 0.87 \\
\hline 5 & 103 & 479 & 222 & 102 & 244 & 0.42 & 2.0 & 0.91 \\
\hline 6 & 97 & 427 & 203 & 241 & 222 & 0.44 & 1.9 & 0.92 \\
\hline 7 & 93 & 393 & 191 & 209 & 203 & 0.46 & 1.9 & 0.94 \\
\hline 8 & 90 & 350 & 177 & 186 & 186 & 0.48 & 1.9 & 0.95 \\
\hline 9 & 87 & 324 & 168 & 184 & 172 & 0.51 & 1.9 & 0.98 \\
\hline 11 & 85 & 289 & 157 & 188 & 147 & 0.58 & 2.0 & 1.1 \\
\hline 12 & 82 & 272 & 150 & 148 & 136 & 0.61 & 2.0 & 1.1 \\
\hline 13 & 81 & 263 & 146 & 258 & 126 & 0.64 & 2.1 & 1.2 \\
\hline 14 & 79 & 246 & 139 & 99 & 117 & 0.67 & 2.1 & 1.2 \\
\hline 15 & 78 & 237 & 136 & 116 & 108 & 0.72 & 2.2 & 1.3 \\
\hline 16 & 77 & 220 & 130 & 65 & 100 & 0.77 & 2.2 & 1.3 \\
\hline 17 & 76 & 212 & 127 & 77 & 93 & 0.82 & 2.3 & 1.4 \\
\hline 18 & 75 & 203 & 124 & 100 & 86 & 0.88 & 2.4 & 1.4 \\
\hline
\end{tabular}

This modeling study was primarily performed to help develop soil sampling plans and to identify likely contributions of wind blown lead to surrounding communities, not as rigorous model validation study. Therefore, additional statistical analyses comparing modeled to measured concentrations beyond those already addressed are not currently warranted. In general, it can be said that the model, input data, and modeling assumptions used in this analysis seem to have perform very well, and that the results should be viewed as a valuable tool in overall site assessment and remediation. 


\section{REFERENCES}

1. Winges, K. D. User's Guide for the Fugitive Dust Model (FDM) (revised), User's Instructions, U.S. Environmental Protection Agency, Office of Air Quality Planning and Standards: Seattle, WA, 1992; EPA-910/9-88-202R.

2. Cowherd, C.; Englehart, P.J.; Muleski, G.E.; Kinsey, J.S. "Hazardous Waste TSDF Fugitive Particulate Matter Air Emissions Guidance Document,” U.S. Environmental Protection Agency, Office of Air Quality Planning and Standards, 1989; EPA-450/3-89019.

3. Cowherd, C.; Muleski, G.E.; Englehart, P.J.; Gillette, D.A. "Rapid Assessment of Exposure to Particulate Emissions from Surface Contamination Sites," U.S.

Environmental Protection Agency, Office of Health and Environmental Assessment, 1985; EPA/600/8-85/002.

4. Gillette, D.A. "Production of dust that may be carried great distances," IN Desert Dust: Origin, Characteristics, and Effect on Man; Geological Society of America Special Paper 186, 1981; 11-26.

5. Compilation of Air Pollutant Emission Factors, Fifth Edition; U.S. Environmental Protection Agency, Office of Air Quality Planning and Standards, 1995.

6. Gillette, D.A. "On the production of soil wind erosion aerosols having the potential for long range transport," J. Rech. Atmos., 1974, 8, 735-744.

7. Gillette, D.A. "Threshold velocities for input of soil particles into the air by desert soils," J. Geophys. Res., 1980, 85, 5621-5630.

8. Gillette, D.A. "Threshold friction velocities and rupture modulii for crusted desert soils for the input of soil particles into the air," J. Geophys. Res., 1982, 87, 9003-9015.

9. Lettau, H. "Note on aerodynamic roughness--parameter estimation on the basis of roughness element description," J. Appl. Meteorol., 1969, 5, 828-832.

10. Wixson, B.G.; Gale, N.L.; Davies, B.E. "A study on the possible use of chat and tailings from the old lead belt of Missouri for agricultural limestone," prepared for Missouri Department of Natural Resources; Jefferson City, MO, 1983.

11. User's Guide for the Industrial Source Complex (ISC3) Dispersion Models; U.S. Environmental Protection Agency, Office of Air Quality Planning and Standards: Research Triangle Park, 1995; EPA-454/B-95-003a.

12. Fed. Reg. "Guideline on Air Quality Models (Revised), Supplement C, 40 CFR Part 51, Appendix W," Final Rule, August 9, 1995; 40465-40474.

13. "Comparison of a Revised Area Source Algorithm for the Industrial Source Complex Short-Term Model and Wind Tunnel Data," U.S. Environmental Protection Agency, 
Office of Air Quality Planning and Standards: Research Triangle Park, NC. 1992.

14. "Superfund Record of Decision: Bunker Hill Mining \& Metallurgical Complex, ID," U.S. Environmental Protection Agency, Office of Emergency and Remedial Response, 1992.

15. "Superfund Record of Decision: Hanford 1100-Area, WA," U.S. Environmental Protection Agency, Office of Emergency and Remedial Response, 1993.

16. Scott, P.K.; Finely, B.L.; Sung, H-M.; Schulze, R.H.; Turner, D.B.; "Identification of an accurate soil suspension/dispersion modeling method for use in estimating health-based soil cleanup levels of hexavalent chromium ore processing residues," J. Air Waste Manage. Assoc. 1997, 47, 753-765.

17. PCRAMMET User's Guide; U.S. Environmental Protection Agency, Office of Air Quality Planning and Standards: Research Triangle Park, August 1998.

18. Preliminary Remediation Goals, U.S. Environmental Protection Agency Region 9, on-line, May 1999.

19. Hosker, R. P. Jr., "Flow and Diffusion Near Obstacles," in Atmospheric Science and Power Production, D. Randerson (Ed.), DOE/TIC-27601, 1984. 


\section{Appendix A}

\section{Modeled Deposition Rates}



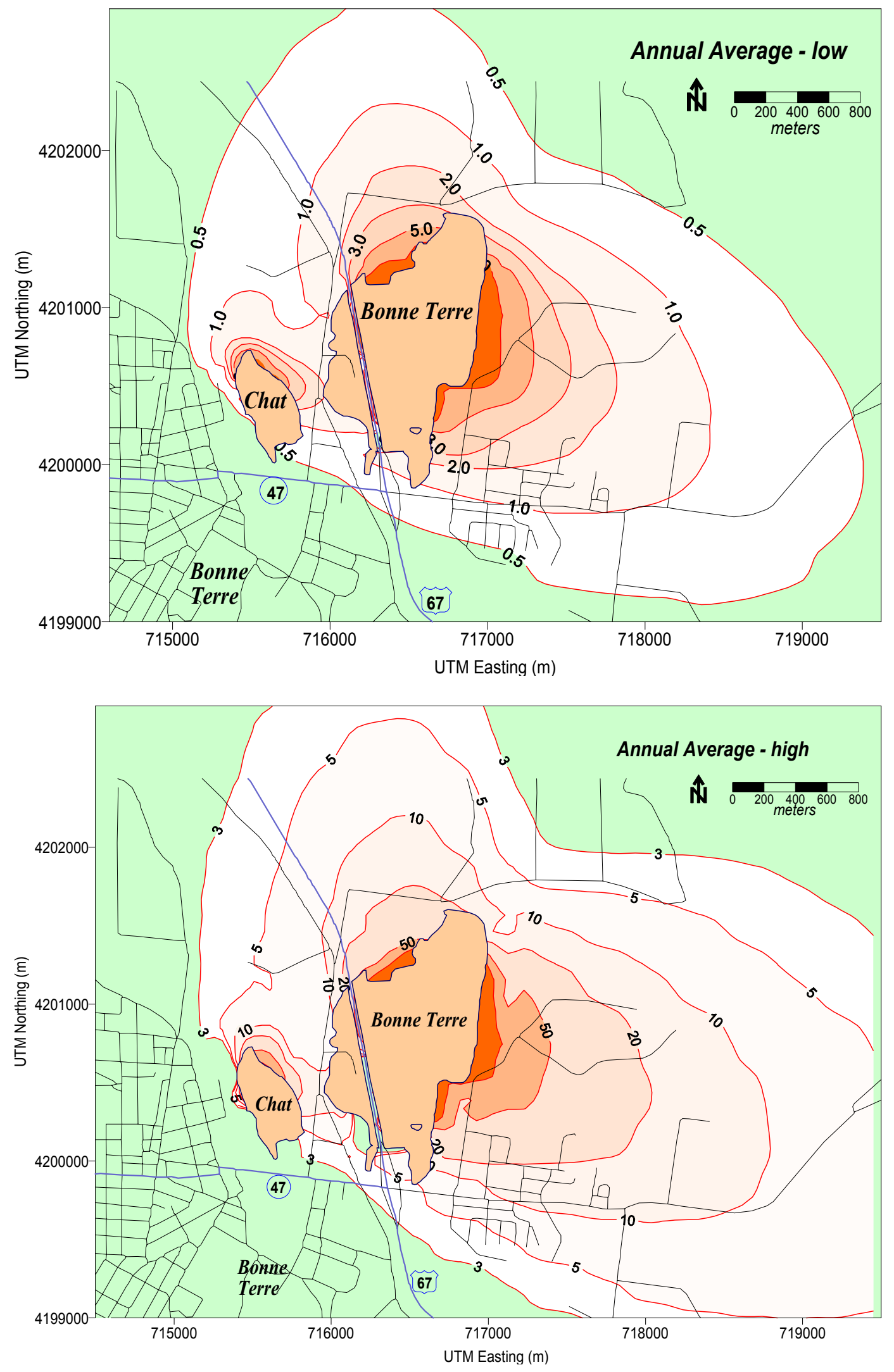
(Deposition rates in $\mu \mathrm{g} \mathrm{m}^{-2} \mathrm{hr}^{-1}$ ) 


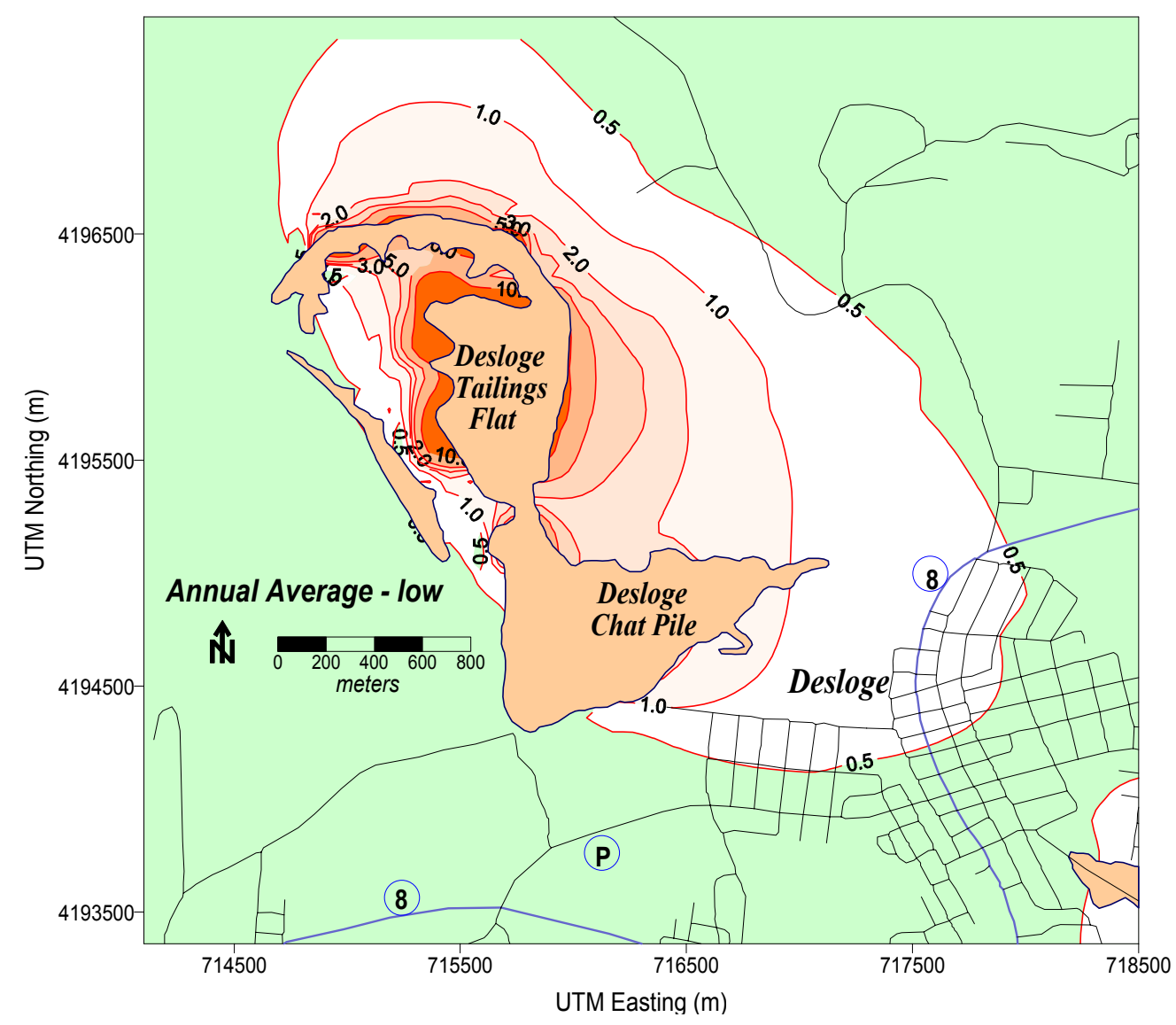

(Deposition rates in $\mu \mathrm{g} \mathrm{m}^{-2} \mathrm{hr}^{-1}$ )

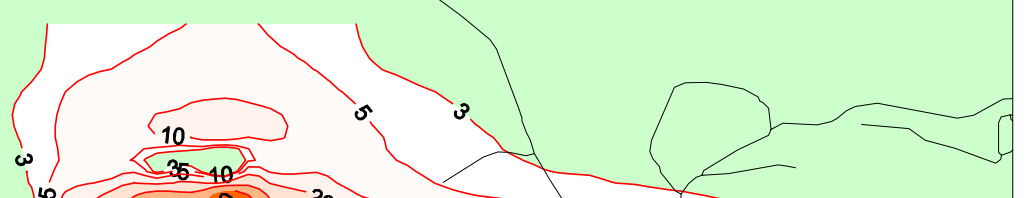




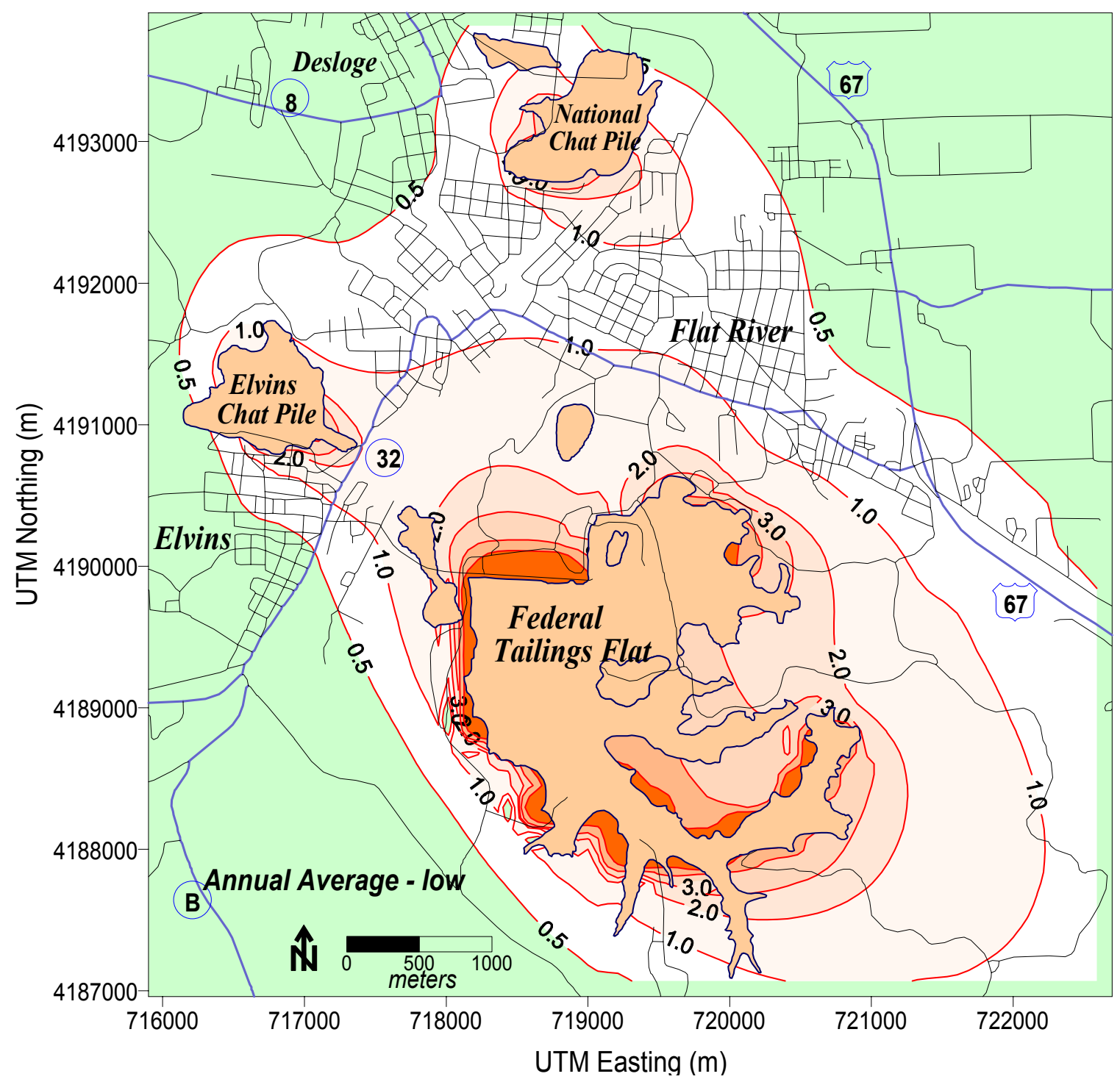


(Deposition rates in $\mu \mathrm{g} \mathrm{m}^{-2} \mathrm{hr}^{-1}$ ) 


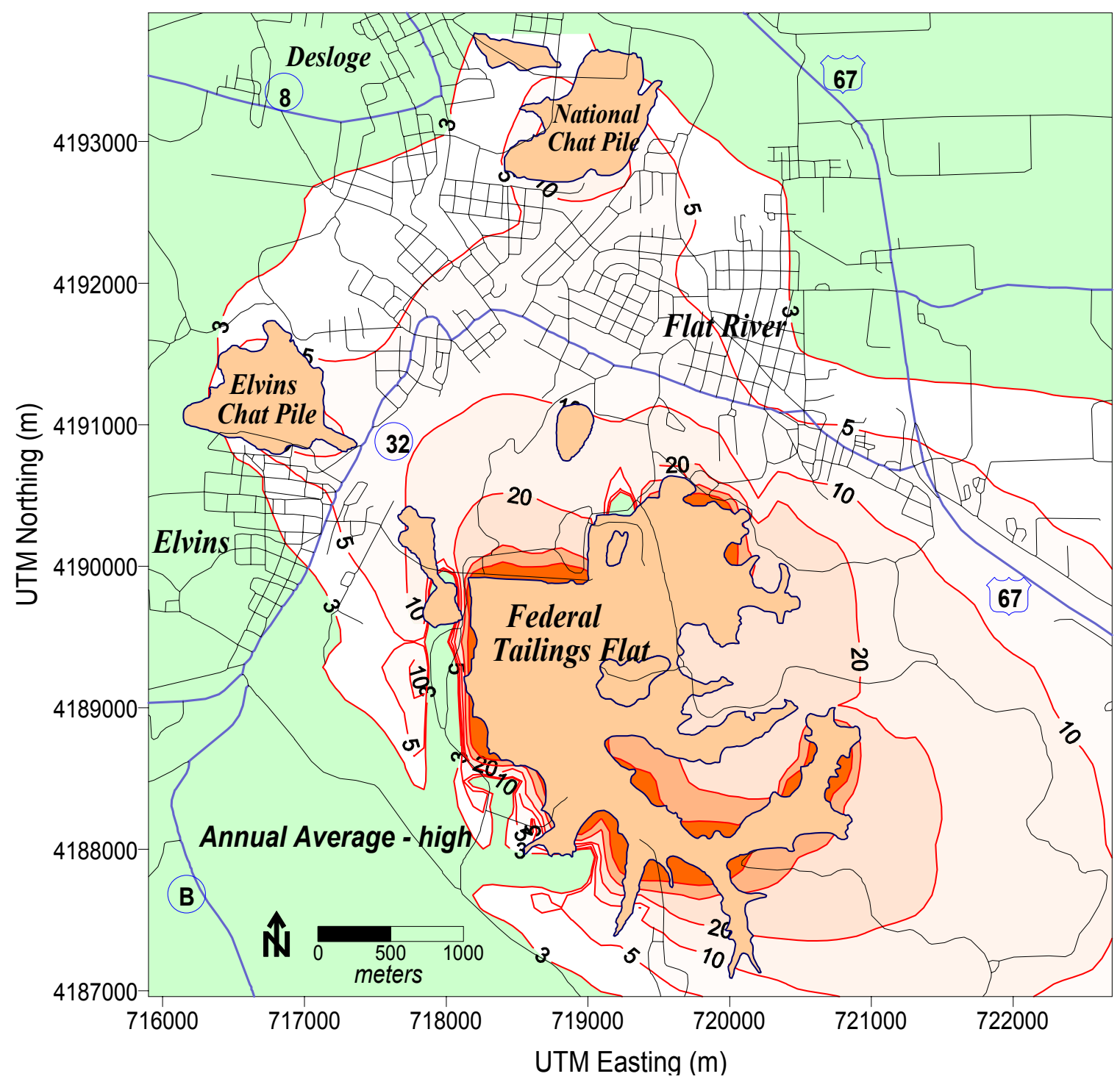


(Deposition rates in $\mu \mathrm{g} \mathrm{m}^{-2} \mathrm{hr}^{-1}$ ) 


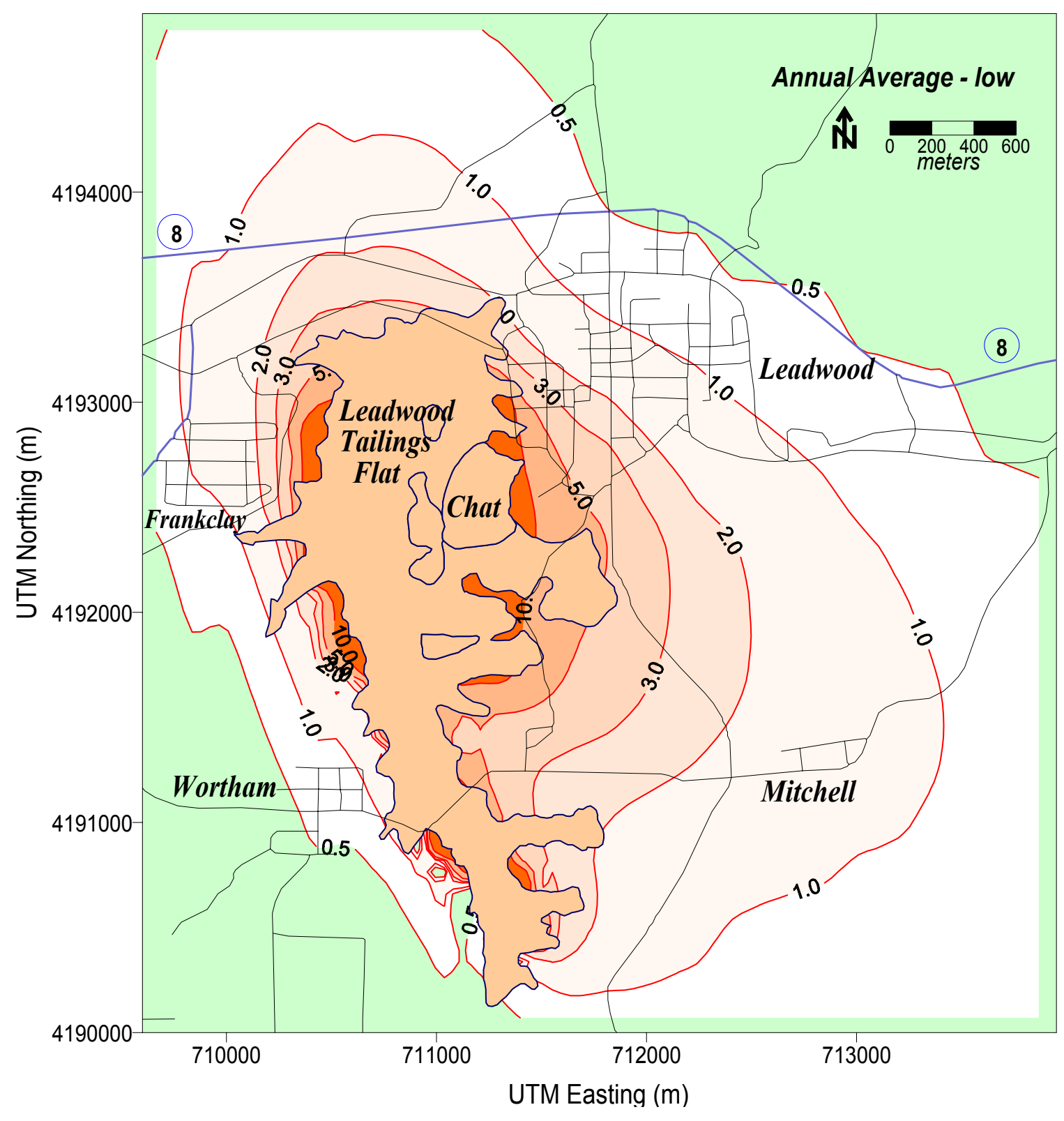


(Deposition rates in $\mu \mathrm{g} \mathrm{m}^{-2} \mathrm{hr}^{-1}$ ) 


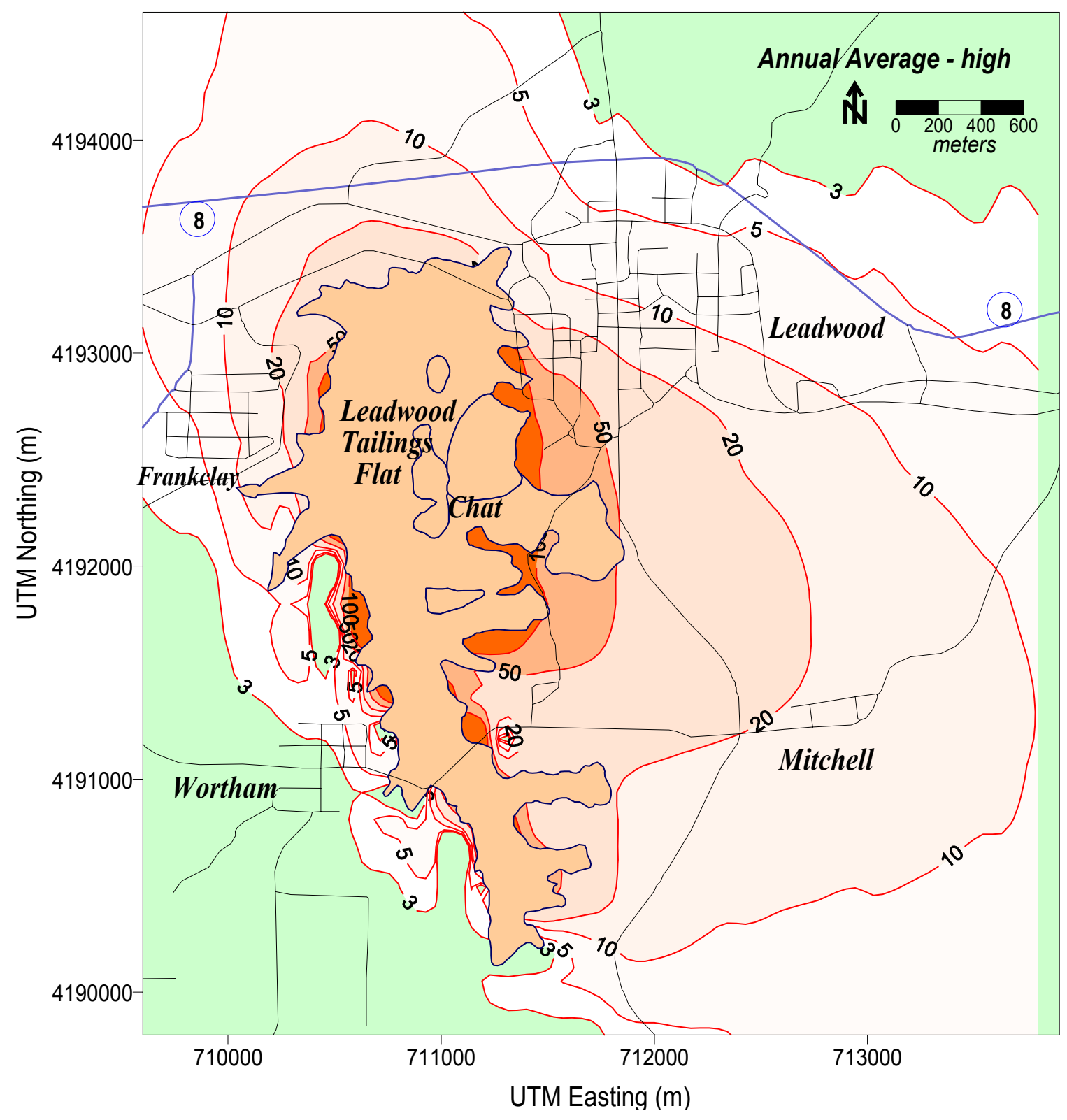


(Deposition rates in $\mu \mathrm{g} \mathrm{m}^{-2} \mathrm{hr}^{-1}$ ) 

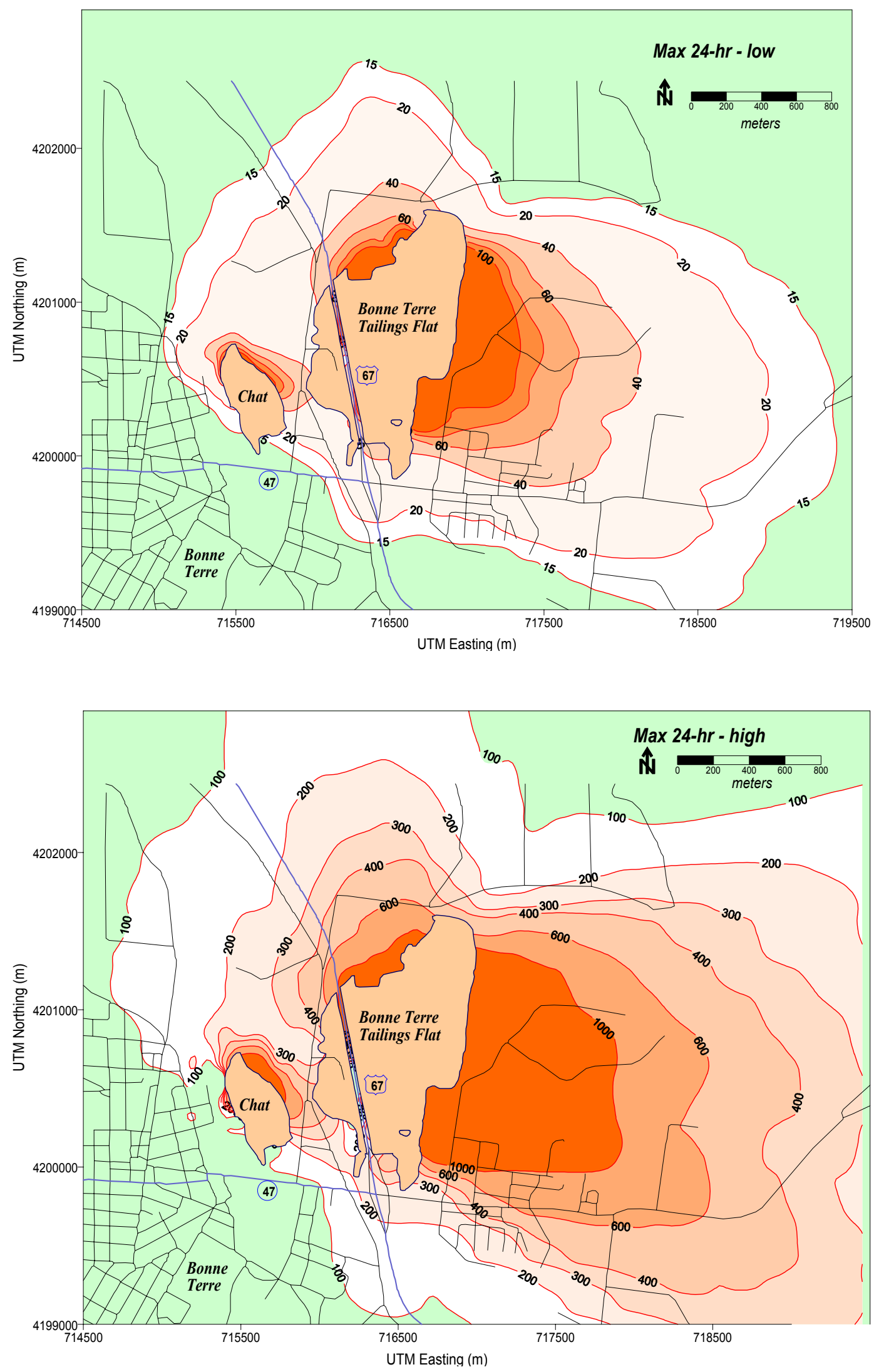
(Deposition rates in $\mu \mathrm{g} \mathrm{m}^{-2} \mathrm{hr}^{-1}$ ) 


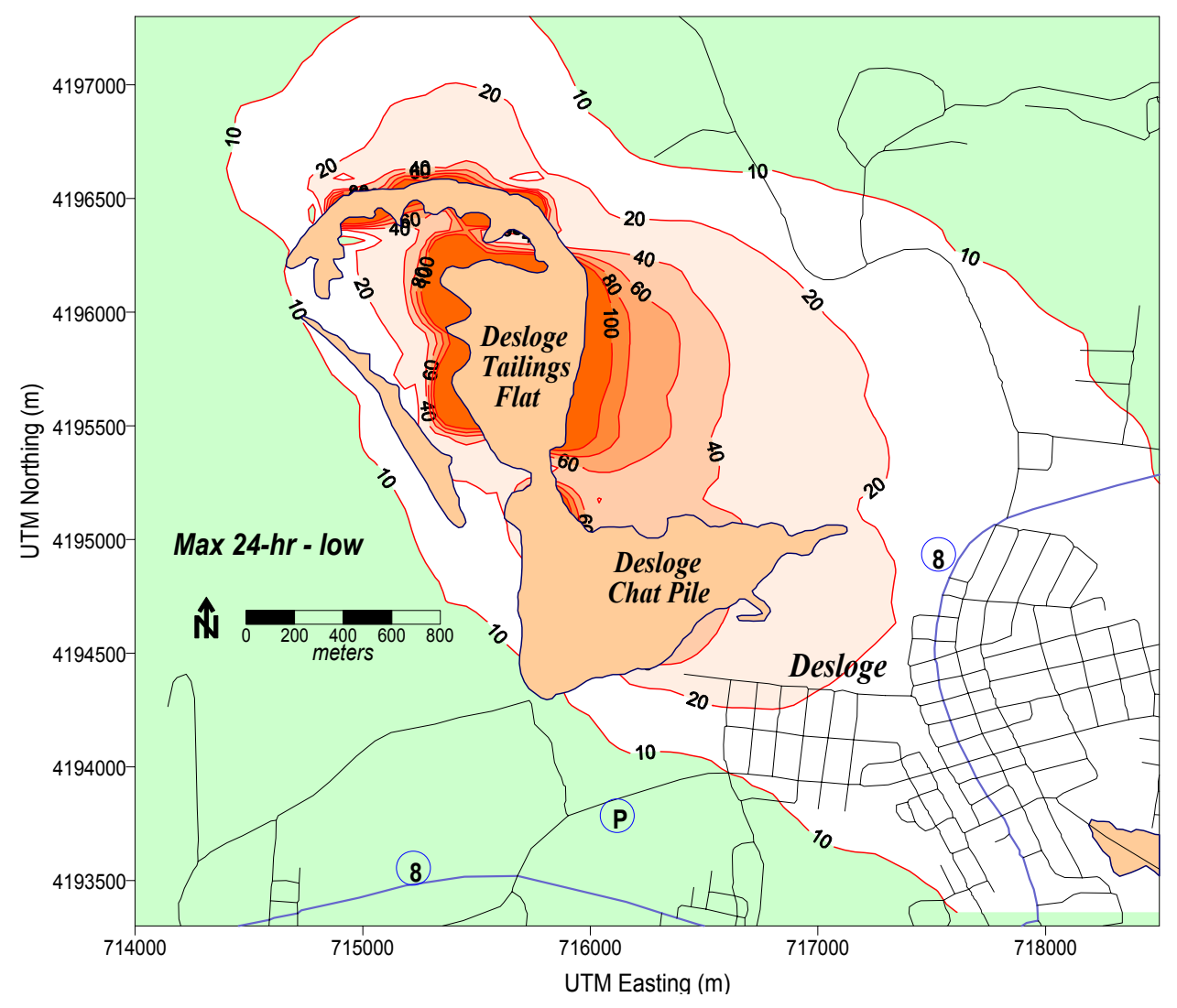

-1 )

(Deposition rates in $\mu \mathrm{g} \mathrm{m}^{-2} \mathrm{hr}$

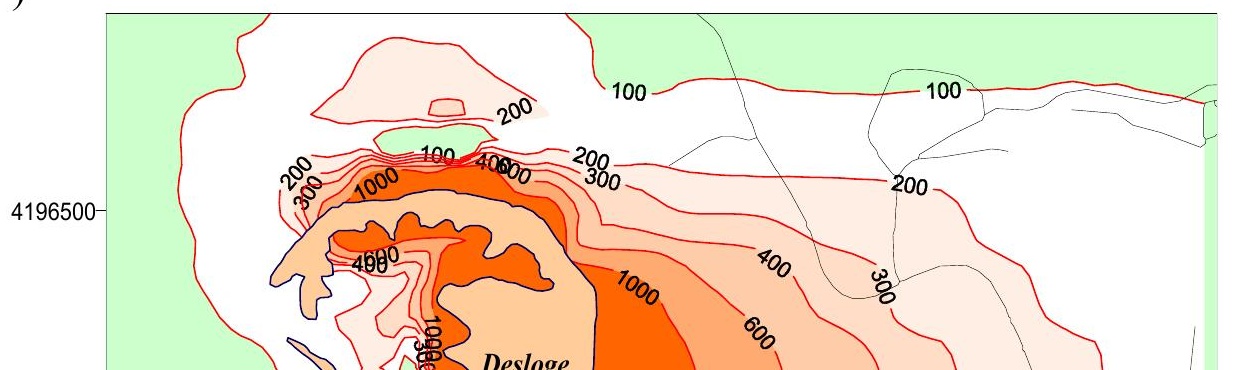




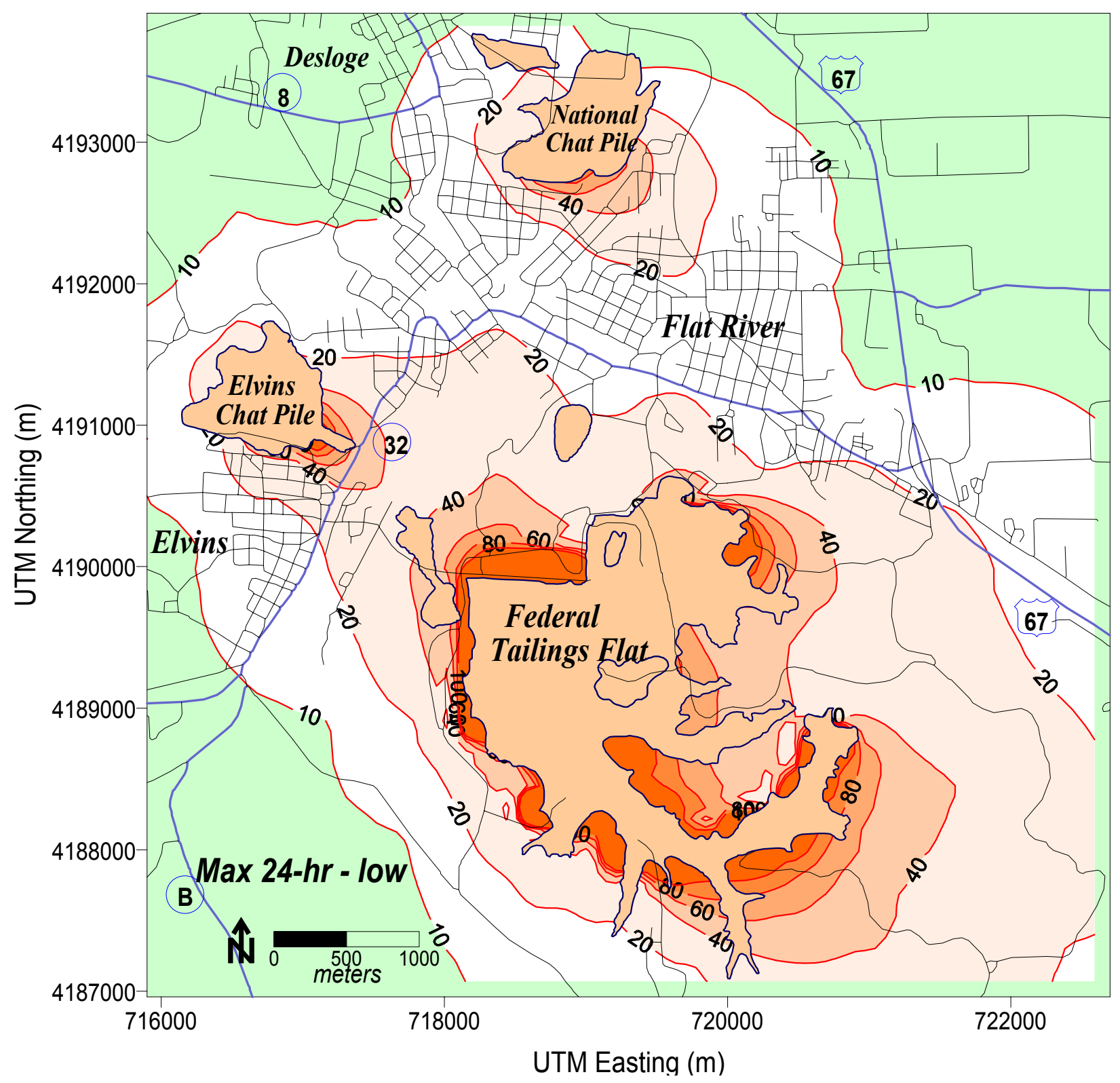

(Deposition rates in $\mu \mathrm{g} \mathrm{m}^{-2} \mathrm{hr}^{-1}$ ) 


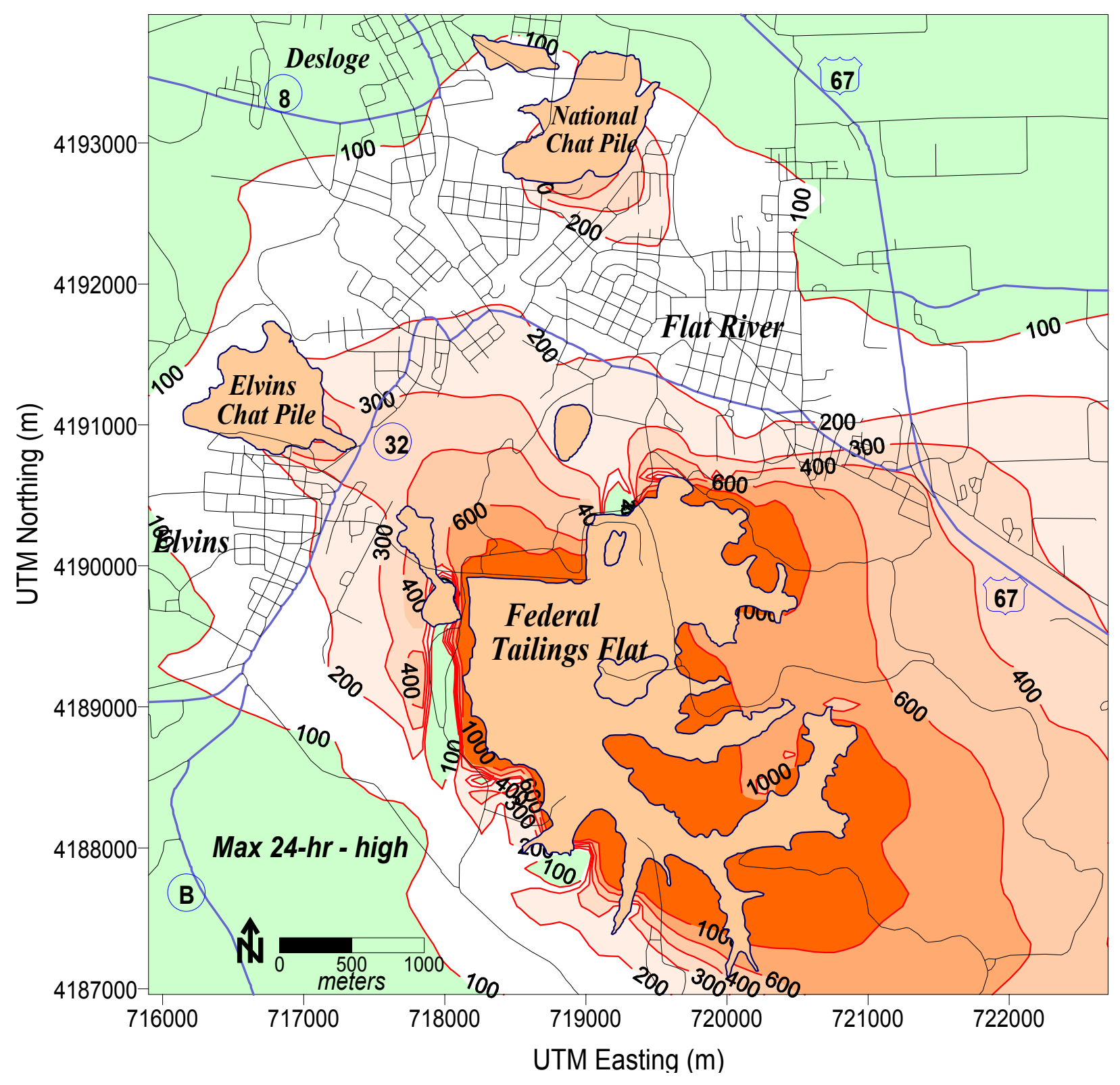

(Deposition rates in $\mu \mathrm{g} \mathrm{m}^{-2} \mathrm{hr}^{-1}$ ) 


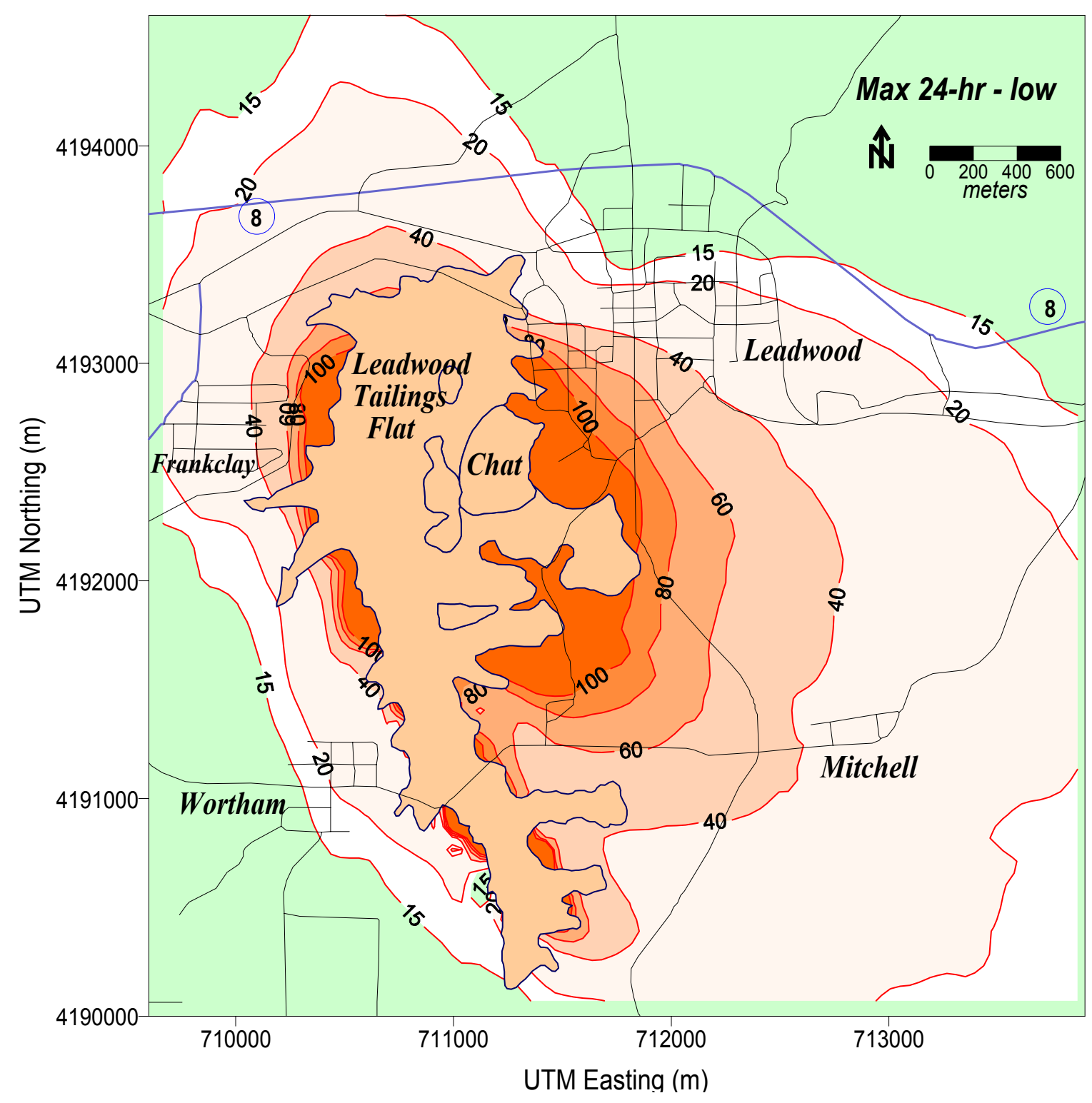


(Deposition rates in $\mu \mathrm{g} \mathrm{m}^{-2} \mathrm{hr}^{-1}$ ) 


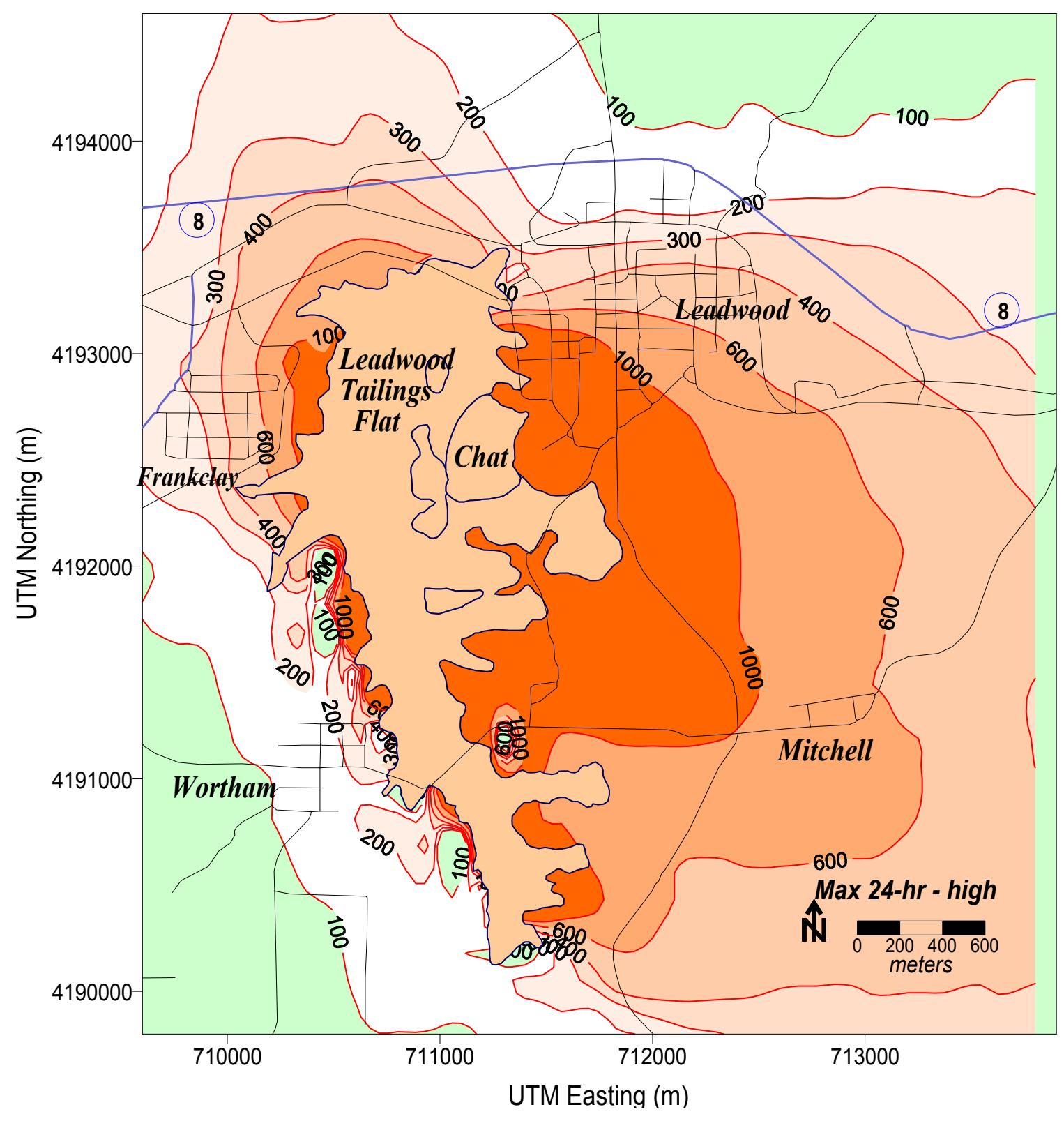


(Deposition rates in $\mu \mathrm{g} \mathrm{m} \mathrm{m}^{-2} \mathrm{hr}^{-1}$

aDraft Laboratory Test Report from GeoSyntec Consultants, 1995.

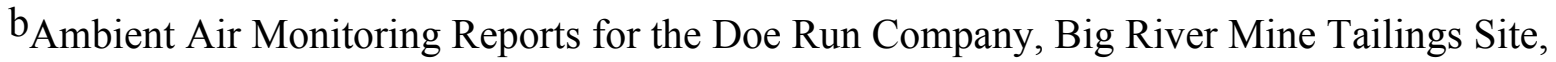
Shell Engineering \& Associates, Inc, 10/31/95 through 4/30/97. 